\title{
Cage Compounds with Main-Group Metals
}

\author{
MICHAEL VEITH \\ Universität des Saarlandes, Anorganische Chemie, D-6600 Saarbrücken, Federal Republic of Germany
}

Received June 26, 1989 (Revised Manuscript Received October 9, 1989)

\section{Contents}

I. Introduction

II. Formation of Cages Incorporating Metals and Nonmetals
A. The Principle of Lewis Acid-Base Interactions
B. Orbital Participation at the Element

III. Cages with Metallic Elements

A. Metal Derivatives of Organic Compounds

B. Metal Amides

1. Silazane Cages Incorporating Lithium, Sodium, Magnesium, Calcium, and Aluminum

2. Iminoalanes and Related Cages

3. Iminogermylenes, Iminostannylenes, Iminoplumbylenes, and Related Cages

4. Cages with $\mathrm{TI}(\mathrm{I}), \mathrm{Ge}(\mathrm{II}), \mathrm{Sn}(\mathrm{II})$, Nitrogen, and Oxygen as Main Components

C. Metal Alkoxides

1. Cages Formed by Metal Alkoxides and Related Compounds

2. Cages Incorporating $\mathrm{Ge}(\mathrm{II}), \mathrm{Sn}(\mathrm{II})$, or $\mathrm{Pb}$ (II), Metal Alkoxides, and Main-Group Metals

D. Some Remarks on Metal/Nonmetal Cages and Uses

IV. Conclusion

V. Acknowledgments

VI. References

\section{Introduction}

The word "cage" is normally associated with a closed pattern in the middle of which something is located. Thus we assume that in a birdcage there should be a bird. In chemistry the term "cage" is more widely used: it is first of all a polycyclic compound that contains atoms connected with one another in such a way that an enclosed volume is created. In this volume no atom or atomic group needs to be situated, and often there is no place for even a hydrogen atom.

The smallest closed polycyclic body is the highly symmetrical tetrahedron. Other bodies of high symmetry that can be constructed from regular rings with three, four, or five corners include the octahedron, the cube, the dodecahedron, and the icosahedron, which together with the tetrahedron constitute the Platonic solids (already known in the megalith era; see also Figure 1). ${ }^{1}$ Three of these highly strained bodies have been synthesized in a carbon skeleton in the form of tetra-tert-butyltetrahedrane,$^{2}$ cubane ${ }^{3,4}$ and dodecahedrane. $^{5}$ Other highly strained organic cages are prismane,${ }^{6}$ pentaprismane,${ }^{7}$ and triasterane.$^{8}$ 


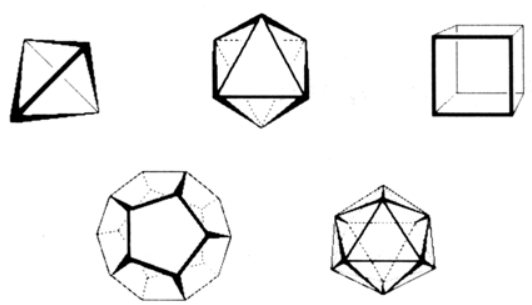

Figure 1. The Platonic solids.

sified as heteroatomic and that incorporate besides the light nonmetals $\mathrm{C}, \mathrm{N}$, and $\mathrm{O}$ metallic main-group elements. Whereas some 10 years ago only a few of these compounds were known, in recent years tremendous progress in this field has been made. Following a classical separation, we will consider elements of main groups I, II, and III (except boron) as well as the heavier elements of group IV, $\mathrm{Ge}, \mathrm{Sn}$, and $\mathrm{Pb}$, as metallic. Terminal donor ligands on these metals will be mostly avoided in these comparisons because they may considerably influence the electrophilicity on the metal. This effect is briefly discussed in section III.D. Our restriction to the hard nonmetals $\mathrm{C}, \mathrm{N}$, and $\mathrm{O}$ (in Pearson's concept) is due to the fact that bonding and chemistry are considerably changed when going from $\mathrm{N}$ to $\mathrm{P}$, As, etc. or $\mathrm{O}$ to $\mathrm{S}$, Se, and Te (d-orbital participation). ${ }^{14}$ In order to give a concise, coherent, and clear description of molecular cages, we have not considered these heavier nonmetals, although they have attracted more attention quite recently in combination with main-group and transition metals. ${ }^{15}$ We will therefore deal exclusively with metal alkyls or aryls, metal amides, metal alkoxides, and related compounds.

It is not within the scope of this article to give a complete description of all the compounds known at this time, but to work out common principles of the chemistry and structures of these molecular derivatives of metals.

\section{Formation of Cages Incorporating Metals and Nonmetals}

\section{A. The Principle of Lewis Acid-Base Interactions}

If a metallic element $M$ is near a nonmetallic element $\mathrm{X}$, which may have a further ligand $\mathrm{R}$ atttached to it, two different kinds of bonding must be envisaged as depicted in formulas A and B.

$$
\left[\mathrm{M}^{+}(\mathrm{I} \underline{\bar{x}}-\mathrm{R})^{-}\right]_{n \rightarrow \infty}
$$

A

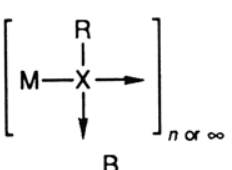

Case A. In this case, the difference in electronegativity between the metal $\mathrm{M}$ and the nonmetal $\mathrm{X}$ is high. The electron pair that may be attributed to the M-X bond is completely shifted to the nonmetal X, resulting in a pair of ions. Such a pair of ions exhibits attraction and repulsion toward other pairs of ions, leading to an ionic lattice if the ligand $\mathrm{R}$ is small or not at all present. In the lattice two principles of packing are important: Each cation or anion tends to surround itself with as many species of the opposite sign as possible, and the number of partners (coordination number) is dependent on the relative size of the cation and anion; e.g., in
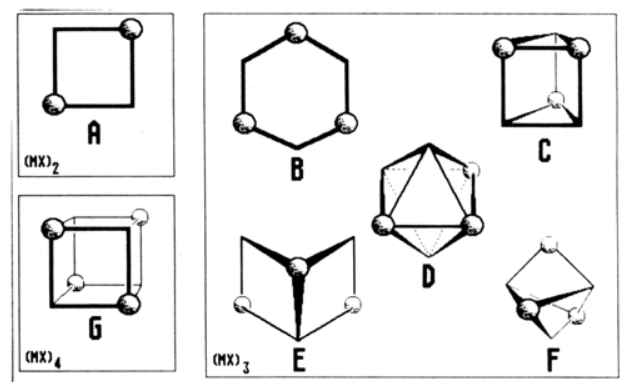

Figure 2. Arrangements of two-, three-, and four-species MX (see text). Here and in subsequent figures the balls represent the location of the metals whereas the nonmetals are found in the corners.

sodium chloride the coordination numbers of $\mathrm{Na}^{+}$and $\mathrm{Cl}^{-}$are 6 , whereas in cesium chloride the corresponding numbers for $\mathrm{Cs}^{+}$and $\mathrm{Cl}^{-}$are 8 .

Things become less straightforward if the ligand $\mathrm{R}$ is bulky. Whereas potassium methoxide can be described at first sight as an ionic lattice, ${ }^{16}$ the structure of potassium tert-butoxide is built up of tetrameric units, $\mathrm{K}_{4}(\mathrm{O}-t-\mathrm{Bu})_{4}$, which are packed in a van der Waals lattice. ${ }^{16 \mathrm{~b}}$ Thus, the ligand $\mathrm{R}$ may change completely the structure and nature of the compound: whereas $\mathrm{MeOK}$ is insoluble in nonpolar organic solvents, $t$ BuOK dissolves in benzene or hexane.

In monographs on metal alkoxides ${ }^{17}$ Bradley and Mehrotra have stated that the bulkiness of the organic ligand influences the "aggregation state" of the alkoxide under consideration. There is a general rule: the more the steric crowding becomes important, the less will be the tendency to form an ionic lattice, even with highly electropositive metallic elements.

There are two ways to explain the bonding in oligomeric species such as $(\mathrm{KO}-t-\mathrm{Bu})_{4}$. One is based on Lewis acid-base interactions as explained in case B later on. The other merely uses an ionic model: two or more pairs of ions will tend to associate in such a form that the coordination numbers of the cation and anion are maximized, in order to obtain a balance between attraction and repulsion.

Thus, for two pairs of $\mathrm{M}^{+} \mathrm{X}^{-}$ions, as found for $\left(\mathrm{Na}^{+} \mathrm{Cl}^{-}\right)_{2}$ in the gas phase, ${ }^{18}$ the structure will be a four-membered, planar, lozenge-shaped ring. If a further pair of $\mathrm{M}^{+} \mathrm{X}^{-}$is added, an arrangement of cations and anions in a regular six-membered cycle with low coordination numbers (cn) of 2 at the two elements may be envisaged (Figure 2B). A disposition of the cations and anions in a polyhedron such as the trigonal prism or the octahedron would contrarily favor higher coordination numbers but would lead to high repulsion of equally charged species (Figure 2C,D). There is only one way to increase the coordination number and to avoid the repulsion at the same time: within the $\mathrm{M}^{+}$ and $\mathrm{X}^{-}$species a separation into less and more coordinated ions has to be made. Two figures result from these considerations: a bicyclic body with two fourmembered cycles sharing a common edge (Figure $2 \mathrm{E}$ ), and a bisphenoid (elongated tetrahedron) with two singly bridged opposite edges (Figure $2 F$ ). In the first case $1 \mathrm{M}^{+}$and $1 \mathrm{X}^{-}$are threefold coordinated, whereas in the second case $2 \mathrm{M}^{+}$and $2 \mathrm{X}^{-}$have more neighbors than the remaining ones. With four $\mathrm{M}^{+} \mathrm{X}^{-}$units the resulting arrangement is straightforward: it is a cube, the corners of which are alternately occupied by metals 
and nonmetals (Figure 2G). It can also be described as two interpenetrating tetrahedra of cations and anions; every atom has a coordination number of 3 . With respect to the oligomers $(\mathrm{MX})_{2}$ and $(\mathrm{MX})_{3}$, the cube structure of $(\mathrm{MX})_{4}$ has two advantages: the disposition of the cations and anions is ideal, and the coordination numbers are relatively high. It is not astonishing that such an arrangement of $\mathrm{M}$ and $\mathrm{X}$ is very common in "heteronuclear cage chemistry".

There is an alternative way to describe the (KO- $t$ $\mathrm{Bu})_{4}$ tetramer, still with an ionic model. Starting with the solid structure of $\mathrm{KCl}$, a cube can be cut out of the ionic lattice that has exactly the disposition of $\mathrm{M}^{+}$and $\mathrm{X}^{-}$as in $(\mathrm{KO}-t-\mathrm{Bu})_{4}$, the tert-butoxide ligands replacing the chloride ions. The existence of $(\mathrm{KO}-t-\mathrm{Bu})_{4}$ can thus be attributed to a prevention of further aggregation due to the bulky tert-butyl groups.

Case $B$. If the difference in electronegativity between the metallic element $M$ and the nonmetallic element $\mathrm{X}$ is small, the $\mathrm{M}-\mathrm{X}$ bond becomes more important and a two-center, two-electron bond has to be considered. This bond, in contrast to the ionic interaction, will be more directional. However, as the metal $\mathrm{M}$ still is highly electron attractive, a compound $\mathrm{RX}-\mathrm{M}$ will tend to "satisfy this handicap" by aggregation through the nonbonding electron pairs on the nonmetal $\mathrm{X}$ of further molecular units. As a result, species RX-M will aggregate as in the ionic model just discussed. The bulkiness of the ligand $R$ will determine the kind and the extent of aggregation; again small ligands will favor a high degree of oligomerization and bulky ligands will favor a small one.

The nature of interaction between the metal and the nonmetal is of the Lewis acid-base or electrophile-nucleophile type. ${ }^{19}$ As already stated, the interaction between the donors and the acceptors is directional. It is therefore important to consider some general features, which are dealt with in the next section.

\section{B. Orbital Participation at the Element}

A Lewis acid-base interaction needs one element with a filled orbital and another element with an empty orbital. ${ }^{19}$ In this article we focus on amides and alcoholates, and thus the donor orbital will be of the $\mathrm{sp}^{3}$ or $\mathrm{sp}^{2}$ type, as $\mathrm{N}$ and $\mathrm{O}$ have the main quantum numbers $n=2$ and thus do generally tend to hybridize. The situation is more complicated at the metal site of the compound. If the element belongs to the main quantum number $n=2(\mathrm{Li}, \mathrm{Be})$, the acceptor orbitals will be $\mathrm{p}$ or $\mathrm{sp}^{2}$ and $\mathrm{sp}^{3}$ if hybridization takes place. A tetrahedral arrangement around these metals will be favored if all orbitals are used. If $n \geq 3$ also the use of $\mathrm{d}$ orbitals in bonding must be envisaged. The coordination sites on the metals should be a trigonal bipyramid $(\mathrm{cn}=5)$ or an octahedron $(\mathrm{cn}=6)$. There is nevertheless a difference between lighter metallic elements with $n=3$ and heavier elements with $n=5$ or $n=6$. The heavier the element, the less a hybridization will be favored, especially if lone-pair electrons on the metal are involved in bonding. To illustrate this, we will consider two compounds, which we will discuss in detail later on, the iminoalane (HAlN-i-Pr) ${ }_{4}{ }^{20}$ and the iminostannylene $(t \text {-BuNSn })_{4} \cdot{ }^{21}$

The two compounds form cubane-like cages with an $\mathrm{Al}_{4} \mathrm{~N}_{4}$ or $\mathrm{Sn}_{4} \mathrm{~N}_{4}$ skeleton, respectively. There is nev-

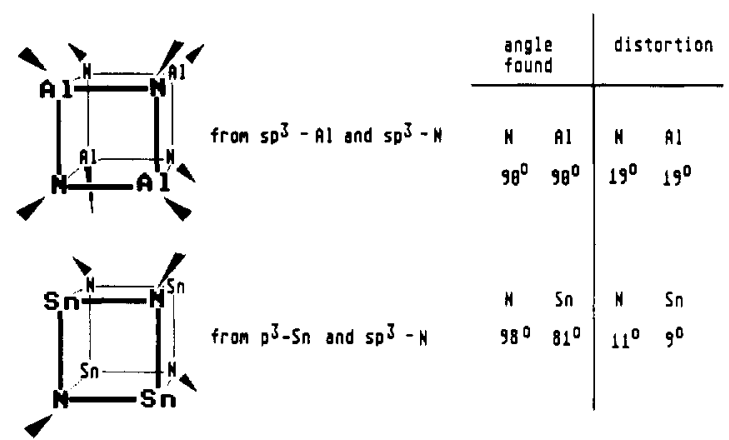

Figure 3. Comparison of bond angles between the two cages $(\mathrm{RAINR})_{4}$ and $(\mathrm{SnNR})_{4}$. The distortion is calculated with respect to the ideal values between two $\mathrm{sp}^{3}$ orbitals or two $\mathrm{p}$ orbitals on the same element.

ertheless a clear difference in the exact geometry. Whereas in the aluminum compound the angles at $\mathrm{Al}$ and $\mathrm{N}$ are very close to $90^{\circ}\left(\mathrm{N}-\mathrm{Al}-\mathrm{N}=89.9^{\circ}, \mathrm{Al}-\mathrm{N}-\mathrm{Al}\right.$ $=90.1^{\circ}$ ), they are different for $\mathrm{Sn}$ and $\mathrm{N}$ in the other compound $\left(\mathrm{N}-\mathrm{Sn}-\mathrm{N}=81.3^{\circ}, \mathrm{Sn}-\mathrm{N}-\mathrm{Sn}=98.1^{\circ}\right)$. To explain this in terms of orbital participation at the elements, the following qualitative description can be used.

In the case of the iminoalane an $\mathrm{sp}^{3}$ hybridization can be attributed to the two elements. The distortion from the tetrahedral angle to the acute angle in the cubic arrangement is equally important for nitrogen and aluminum. In the case of the iminostannylene the nitrogen atom again may be $\mathrm{sp}^{3}$ hybridized, whereas for the low-valent tin atom no hybridization needs to be made, the nonbonding pair being mostly located in an $s$ orbital. 22,23 The acceptor orbitals at tin thus are $p$ orbitals that are disposed at right angles to one another. Combining the $\mathrm{Sn}$ and $\mathrm{N}$ atoms creates a cage that has more acute angles at the tin atoms than at the nitrogen atoms. The distortion from the ideal values is alike for $\mathrm{Sn}$ and $\mathrm{N}$ and amounts to about $10^{\circ}$, whereas in the case of the iminoalane the distortion is about $19^{\circ}$ (See also Figure 3).

On the basis of an ionic model and by considering the different sizes of the metals, it is difficult to work out, if the balance of attraction and repulsion in the two cases would lead to a reasonable explanation for their different structures. Isolated four-coordinate aluminum is mostly found to be tetrahedral $\left(\mathrm{AlCl}_{4}^{-}\right)$, whereas an isolated three-coordinate tin has bonds disposed at almost right angles $\left(\mathrm{SnCl}_{3}{ }^{-}\right) .^{22}$

Until now no oligomeric species other than the tetramer has been found for iminogermylenes, -stannylenes, and -plumbylenes (see later on). Things have turned out to be different in the case of the iminoalanes. Thus, besides (HAlN-i-Pr) ${ }_{4}$ also the hexamer (HAlN$i$-Pr $)_{6}$ is known, and an X-ray structure has been performed on single crystals of this compound. ${ }^{24}$ The $\mathrm{Al}_{6} \mathrm{~N}_{6}$ framework is a hexagonal prismatic cage (see Figure 9B) that has, besides acute angles within the four-membered cycles of the cage, also angles of $116.4^{\circ}$ $(\mathrm{N}-\mathrm{Al}-\mathrm{N})$ and $123.2^{\circ}(\mathrm{Al}-\mathrm{N}-\mathrm{Al})$ within the six-membered rings. Compared to the cubic tetrameric arrangement, the strain in the hexameric arrangement is less. It may be due to such angle distortions that there is a much greater variety of different cages in the iminoalane than in the iminostannylene series.

As stated in section II.A, oligomerization of a species $\mathrm{RX}-\mathrm{M}$ takes place via Lewis acid-base interactions. It 

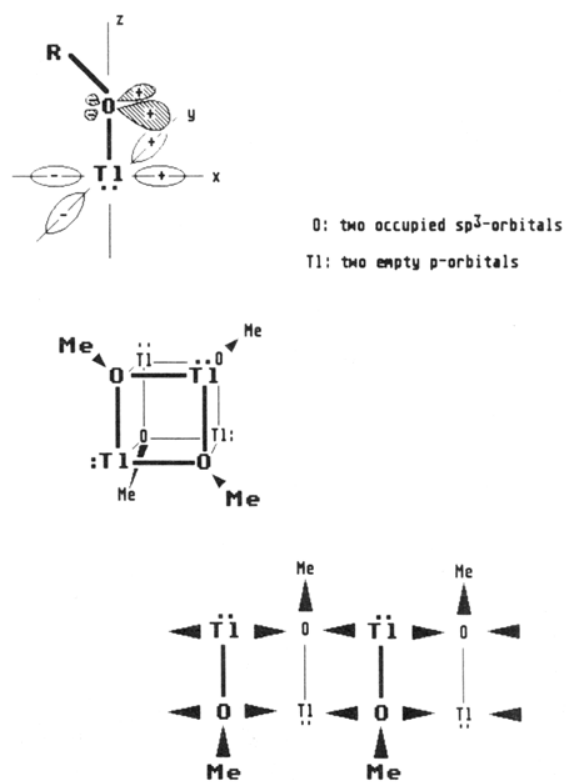

Figure 4. A simplified electronic model for the oligomerization of thallium(I) methoxide. In Lewis theory thallium can be considered as a "double acid", while oxygen is a "double base". The result of interaction may give a tetramer or an oligomer.

is obvious that by merely counting the electron pairs and free orbitals at the elements and by considering the bulkiness of the substituents $R$, it can be predicted when a cage compound should be formed..$^{23}$

To illustrate this, we consider thallium(I) methoxide. First we assume the compound to be monomeric. Counting the electrons in the compound using normal Lewis electron count rules, we find four at thallium and eight at oxygen, which are formally distributed in a nonbonding and a bonding electron pair at the metallic atom and two bonding and two nonbonding pairs at the oxygen atom. In terms of Lewis acid-base theory, the thallium atom is a "double Lewis acid" and the oxygen atom a "double Lewis base". If the acids and bases react intermolecularly, at least two forms of aggregation can be predicted, as depicted in Figure 4: a polymeric arrangement and a cage arrangement. In every case the metals and nonmetals acting as double acids or double bases attain coordination numbers of $3(\mathrm{Tl})$ and $4(0)$ and have in these aggregates electron configurations that are identical with the configurations of the rare gases $\mathrm{Xe}$ and $\mathrm{Ne}$.

It was found more than 25 years ago $0^{25}$ that thallium(I) methoxide is tetrameric, the $\mathrm{Tl}_{4} \mathrm{O}_{4}$ skeleton forming a distorted cube. Even such a small group as the methyl at the oxygen leads in this special example to a cage. If the thallium atom is replaced by tin(II) and the oxygen atom by a nitrogen atom, which leads to the isoelectronic iminostannylene $\mathrm{SnN}-\mathrm{Me}$, the arrangement is definitely not tetrameric but highly oligomeric or polymeric. ${ }^{26}$ This illustrates that the special electronic properties of the elements involved in bonding as well as steric considerations play an important part in the structures of the cages.

A special group of compounds are metal-alkyl cages, as their formation cannot be derived from mere electron counting. As in other cases of electron-deficient molecules, the aggregation of several "monomers" to oligomeric cage units is due to two-electron, multicenter bonds. In methyllithium, which is known to form a $\mathrm{Li}_{4} \mathrm{C}_{4}$ cube, ${ }^{27}$ the bonding is thought to involve several
TABLE I. Selected Cage Compounds of Metal Organyls

\begin{tabular}{|c|c|c|c|}
\hline formula & $\begin{array}{c}\text { C-M } \\
\text { skeleton } \\
\text { of cage }\end{array}$ & $\begin{array}{l}\text { approx geom } \\
\text { of cage }^{b}\end{array}$ & ref \\
\hline $\mathrm{Me}_{4} \mathrm{Li}_{4}$ & $\mathrm{Li}_{4} \mathrm{C}_{4}$ & cube $A$ & 27 \\
\hline $\mathrm{Me}_{4} \mathrm{Na}_{4}$ & $\mathrm{Na}_{4} \mathrm{C}_{4}$ & cube $A$ & 32 \\
\hline $\mathrm{Et}_{6} \mathrm{Li}_{6}$ & $\mathrm{Li}_{6} \mathrm{C}_{6}$ & $\begin{array}{l}\text { six-capped trigonal } \\
\text { antiprism B }\end{array}$ & 33 \\
\hline$t-\mathrm{Bu}_{4} \mathrm{Li}$ & $\mathrm{Li}_{4} \mathrm{C}_{4}$ & cube A & 34 \\
\hline$\left(\mathrm{C}_{6} \mathrm{H}_{11}\right)_{6} \mathrm{Li}_{6} \cdot 2 \mathrm{C}_{6} \mathrm{H}_{6}$ & $\mathrm{LiC}$ & $\begin{array}{l}\text { six-capped trigonal } \\
\text { antiprism B }\end{array}$ & 35 \\
\hline $\mathrm{Me}_{4} \mathrm{Li}_{4}$ (tmeda) $)_{2}$ & $\mathrm{Li}_{4} \mathrm{C}_{4}$ & cube $\mathrm{A}$ & 36 \\
\hline$(\mathrm{PhC} \equiv \mathrm{C})_{4} \mathrm{Li}_{4}(\mathrm{THF})_{4}$ & $\mathrm{Li}_{4} \mathrm{C}_{4}$ & cube $A$ & 37 \\
\hline$(\mathrm{PhC} \equiv \mathrm{C})_{12} \mathrm{Li}_{12}$ (tmeda $)_{6}$ & $\mathrm{Li}_{12} \mathrm{C}_{12}$ & complex structure & 37 \\
\hline$\left[(t-\mathrm{BuC} \equiv \mathrm{C})_{2} \mathrm{CLi}_{2} \cdot \mathrm{OEt}_{2}\right]_{4}$ & $\mathrm{Li}_{8} \mathrm{C}_{12}$ & complex structure & 38 \\
\hline $\mathrm{Ph}_{4} \mathrm{Li}_{4} \cdot 4 \mathrm{Et}_{2} \mathrm{O}$ & $\mathrm{Li}_{4} \mathrm{C}_{4}$ & cube $A$ & 39 \\
\hline$\left(\mathrm{PhLi} \cdot \mathrm{Et}_{2} \mathrm{O}\right)_{3} \cdot \mathrm{LiBr}$ & $\mathrm{Li}_{4} \mathrm{C}_{3} \mathrm{Br}$ & cube $\mathrm{A}$ & 39 \\
\hline $\mathrm{Li}_{2} \mathrm{Br}_{2}\left(\mathrm{c}-\mathrm{C}_{3} \mathrm{H}_{5}\right)_{2} \mathrm{Li}_{2} \cdot 4 \mathrm{Et}_{2} \mathrm{O}$ & $\mathrm{Li}_{4} \mathrm{C}_{2} \mathrm{Br}_{2}$ & cube $\mathrm{A}$ & 40 \\
\hline $\mathrm{Li}_{4}\left(\mathrm{C}_{4}\right.$ & $\mathrm{Li}_{4} \mathrm{C}_{4}$ & cube $\mathrm{A}$ & 41 \\
\hline $\mathrm{Li}_{4}\left[\mathrm{C}_{6} \mathrm{H}_{4}\left(2-\mathrm{CH}_{2} \mathrm{NMe}_{2}\right)\right]_{4}$ & $\mathrm{Li}_{4} \mathrm{C}_{4}$ & cube $\mathrm{A}$ & 42 \\
\hline $\mathrm{Li}\left[2,6-\left(\mathrm{OCH}_{3}\right)_{2} \mathrm{C}_{6} \mathrm{H}_{3}\right]_{4}$ & $\mathrm{Li}_{4} \mathrm{C}_{4}$ & cube $A$ & 43 \\
\hline
\end{tabular}

${ }^{a}$ Here and in all subsequent tables the capital letters following the designation of the approximate geometry refer to the structures shown in the figures. ${ }^{b} \mathrm{Cf}$. Figure 5.
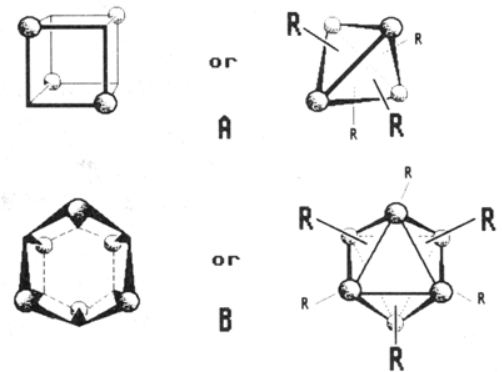

Figure 5. Two possible representations of oligomeric metal alkyls (for further comments see text and Figure 2).

orbitals from lithium as well as the filled $\mathrm{sp}^{3}$ orbital at the methyl group. ${ }^{28}$

\section{Cages with Metallic Elements}

\section{A. Metal Derivatives of Organic Compounds}

Alkyls or aryls of alkali metal and alkaline earth elements are well-known to many chemists as valuable tools in preparative chemistry. They are synthesized mainly by direct interaction of the metals with alkyl or aryl halides (eq 1). ${ }^{29}$

$$
\begin{gathered}
\mathrm{R}-\mathrm{X}+2 \mathrm{M}^{\mathrm{I}} \rightarrow \mathrm{R}-\mathrm{M}^{\mathrm{I}}+\mathrm{M}^{\mathrm{I}} \mathrm{X} \\
\mathrm{R}-\mathrm{X}+\mathrm{M}^{\mathrm{II}} \rightarrow \mathrm{R}-\mathrm{M}^{\mathrm{II}}-\mathrm{X} \\
2 \mathrm{R}-\mathrm{M}^{\mathrm{II}}-\mathrm{X} \rightarrow \mathrm{R}_{2} \mathrm{M}^{\mathrm{II}}+\mathrm{M}^{\mathrm{II}} \mathrm{X}_{2}
\end{gathered}
$$

Most of these compounds are used in polar or nonpolar solvents and many of them have not been subject to structural characterization. As has been found especially with lithium compounds, they have nevertheless a very rich cyclic and polycyclic structural chemistry. ${ }^{28,30}$

In Table I a selection of polycyclic metal alkyls, aryls, acetylides, etc. have been assembled which have a common $\mathrm{M}_{n} \mathrm{C}_{n}$ cage skeleton. As can be seen, lithium compounds are very prominent (for other metals see ref 31). Besides cubic arrangements of metal and carbon atoms, which can also be described as a tetrahedron of lithium atoms with all faces being capped by carbon 
TABLE II. Some Silazane Cages Incorporating Lithium, Sodium, Magnesium, Calcium, and Aluminum

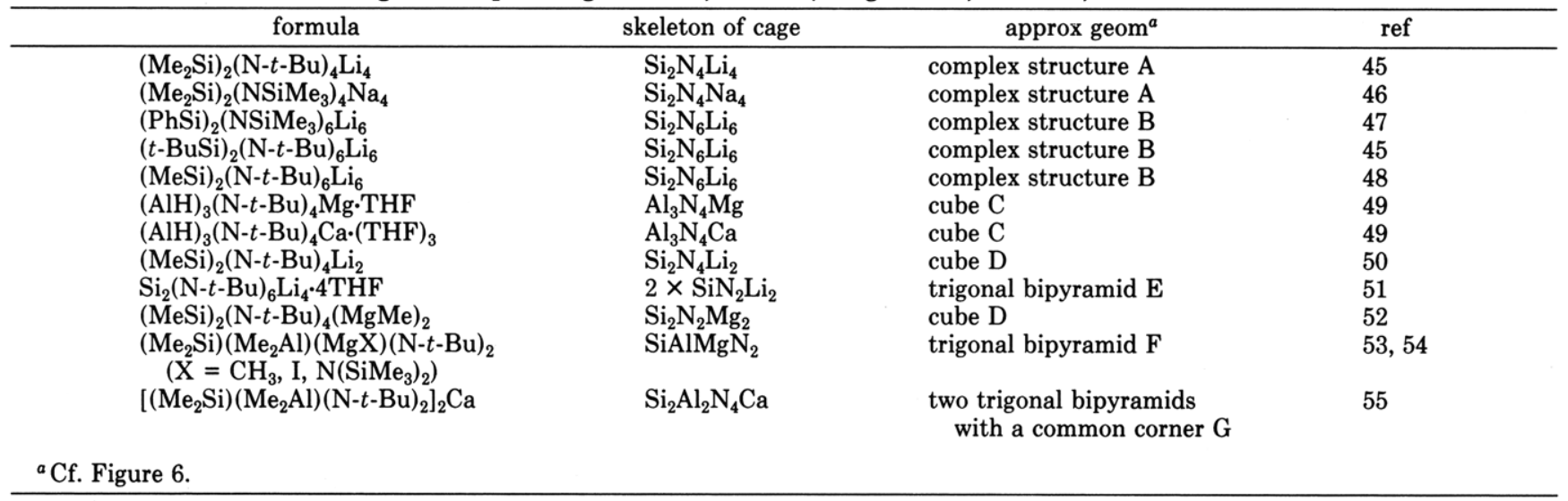

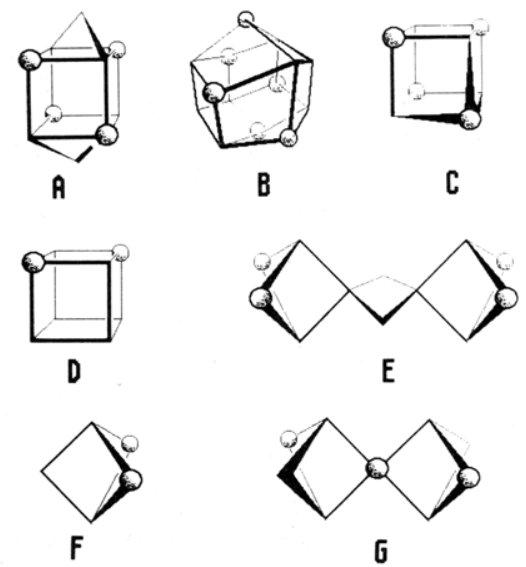

Figure 6. Different cages adopted by metalated silazanes and iminoalanes (the silicon atoms are considered to be nonmetallic and are represented in the form of corners.

atoms, also other arrangements have been found (see Figure 5). In the hexameric oligomers the cage $\mathrm{Li}_{6} \mathrm{C}_{6}$ can be subdivided in a $\mathrm{Li}_{6}$ octahedron, six sides of this being capped by carbon atoms, leading to a $\overline{3}\left(S_{6}\right)$ symmetry. More complex structures have been found in $\left[\mathrm{PhC} \equiv \mathrm{CLi} \cdot{ }^{1} /{ }_{2} \text { (tmeda) }\right]_{12}{ }^{36}$ and in $\left[(t-\mathrm{BuC} \equiv \mathrm{C})_{2} \mathrm{CLi}_{2}\right.$. $\left.\mathrm{OEt}_{2}\right]_{4} \cdot{ }^{37}$ In these compounds terminal carbon atoms and also the $\pi$ electrons of the acetylene part of the molecule are involved in bonding to the lithium atoms. The $\mathrm{Li}_{4} \mathrm{C}_{4}$ cube arrangements may be very much distorted as in $\mathrm{Ph}_{4} \mathrm{Li}_{4} \cdot 4 \mathrm{Et}_{2} \mathrm{O} .^{38} \mathrm{In}$ addition to carbon atoms other nonmetal donors may be involved in the cage as is found for $(\mathrm{PhLi} \cdot \mathrm{OEt})_{3} \cdot \mathrm{LiBr}$ and $\mathrm{Li}_{2} \mathrm{Br}_{2} \cdot(\mathrm{c}-$ $\left.\mathrm{C}_{3} \mathrm{H}_{3}\right)_{2} \mathrm{Li}_{2} \cdot 4 \mathrm{Et}_{2} \mathrm{O}$, bromine replacing the carbon atoms. If solvent donors are present in the compounds, they are always found to be located in a terminal position at the lithium atoms, completing the coordination sphere of the metal. In tetrameric 3-lithio-1-methoxybutane, $\mathrm{Li}_{4}\left(\mathrm{C}_{4} \mathrm{H}_{7} \mathrm{OCH}_{3}\right)_{4}$, the oxygen atoms serve as terminal donors toward the lithium atoms; the cubic $\mathrm{Li}_{4} \mathrm{C}_{4}$ arrangement is bridged at four edges by $\left(\mathrm{CH}_{2}\right)_{2} \mathrm{O}$ arches.

As far as the bonding is concerned in these metal organic cages, multicenter two-electron bonds seem to play an important part. More sophisticated calculations have been performed, some of which are summarized by von Rague Schleyer. ${ }^{28}$ In a very crude approximation the ionic model of section II.A may be used to evaluate the three-dimensional arrangement of the metal atoms and the organic groups in these molecules.

\section{B. Metal Amides}

\section{Silazane Cages Incorporating Lithium, Sodium, Magnesium, Calcium, and Aluminum}

The reactivity of an $\mathrm{N}-\mathrm{H}$ bond is normally increased if silicon is bonded to the nitrogen atom, especially in displacement reactions of hydrogen by metal atoms. ${ }^{44}$ It is therefore relatively easy to introduce metal atoms into silazanes by reacting amines with metal alkyls or activated metals as shown for some selected examples in eq 2.
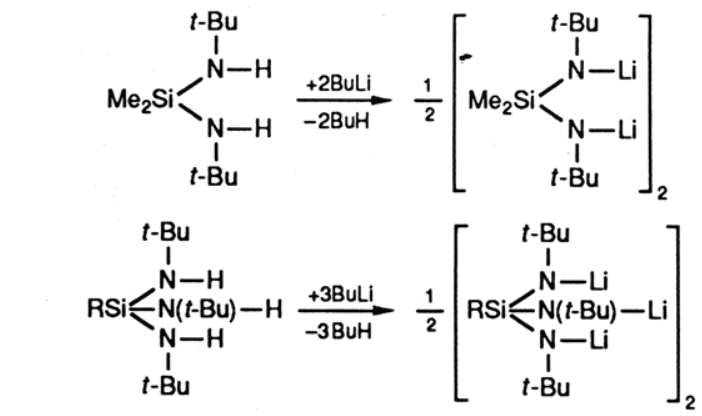

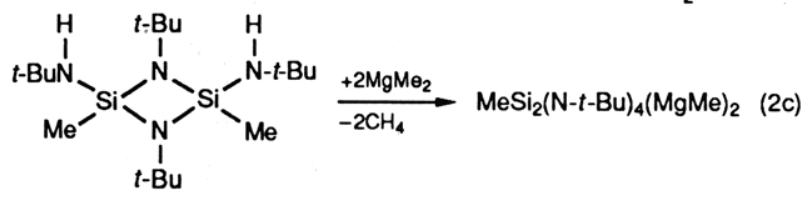

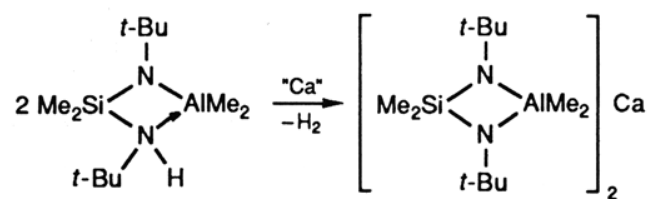

When bulky substituents are used at the nitrogen atoms (as the tert-butyl group in eq 2), the metalated silazanes obtained are often molecular; i.e., they have a low degree of association and can be isolated by crystallization from nonpolar solvents.

In Table II a selection of silazane derivatives are assembled which have metal atoms $(\mathrm{Li}, \mathrm{Na}, \mathrm{Mg}, \mathrm{Ca}, \mathrm{Al})$ bonded to the $\mathrm{N}$ atoms in the $\mathrm{Si}-\mathrm{N}$ framework and which all form cages incorporating $\mathrm{Si}, \mathrm{N}$, and the metals. In Figure 6 the different nonmetal/metal arrangements found in these cages are represented. $\left[\mathrm{Me}_{2} \mathrm{Si}\left(\mathrm{NSiMe}_{3}\right)_{2} \mathrm{Na}_{2}\right]_{2}$ and $\left[\mathrm{Me}_{2} \mathrm{Si}(\mathrm{N}-t-\mathrm{Bu})_{2} \mathrm{Li}_{2}\right]_{2}$ are dimeric by metal/nonmetal interactions; in the middle of the molecules an $\mathbf{M}_{4}$ tetrahedron may be visualized which is coordinated at the four corners by $\mathrm{N}_{2} \mathrm{Si}$ arches (Figure 6A). In an alternative description the lithium 

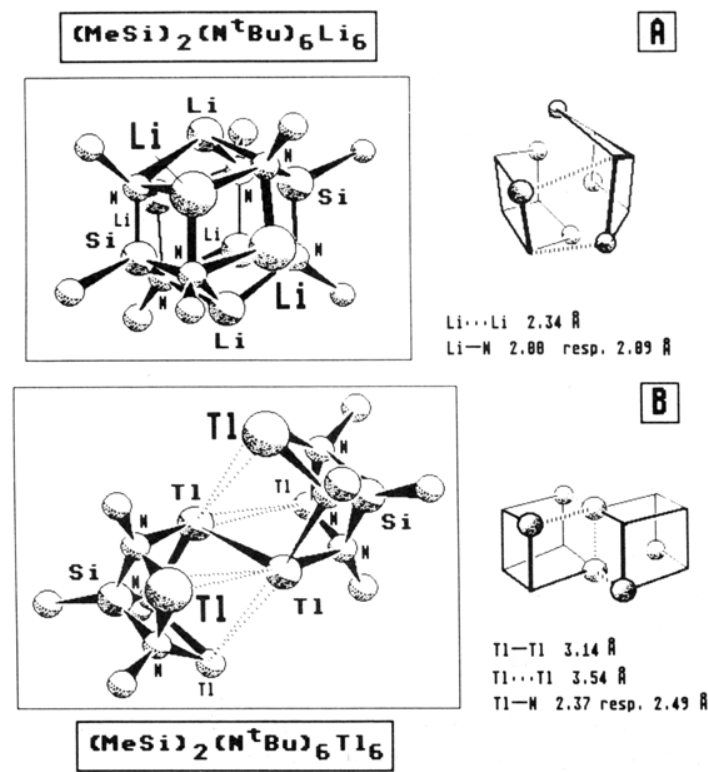

Figure 7. A comparison of the structures of $\left[\mathrm{MeSi}(\mathrm{N}-t-\mathrm{Bu})_{3}\right]_{2} \mathrm{Li}_{6}$ and $\left[\mathrm{MeSi}(\mathrm{N}-t-\mathrm{Bu})_{3}\right]_{2} \mathrm{Tl}_{6} \cdot{ }^{48,75}$ The methyl substitutents on the tert-butyl groups are omitted for clarity. The sketches on the right sides are shown in order to illustrate their correspondence to the structures and to exemplify the origin of the illustrations in Figures 2, 5, 6, 9, 11, and 12.

(sodium) and nitrogen atoms form a distorted cube, which on two opposite faces is bridged diagonally by silicon atoms. The nitrogen atoms are in a peculiar situation as they are coordinated by three metals, a silicon atom, and a carbon atom and hence have $\mathrm{cn}=$ 5 . It is evident that there is no correspondence to simple electron pair counting rules. The authors who studied these molecules considered the interactions to be mostly of the ionic type. ${ }^{45,46}$ Closely related to these molecules are $\left[(\mathrm{PhSi})\left(\mathrm{NSiMe}_{3}\right)_{3} \mathrm{Li}_{3}\right]_{2}$ and $[(\mathrm{RSi})(\mathrm{N}-t$ $\left.\mathrm{Bu})_{3} \mathrm{Li}_{3}\right]_{2}(\mathrm{R}=t-\mathrm{Bu}, \mathrm{Me})$, which form even larger cages. The central cage skeleton may be described as two cubes with one missing corner $\left(\mathrm{SiN}_{3} \mathrm{Li}_{3}\right)$ which interpenetrate in such a way along the threefold axis that every lithium atom becomes threefold coordinated by nitrogen atoms (see Table II and Figures $6 \mathrm{~B}$ and 7A). The lithium atoms themselves are disposed at the corners of a trigonal antiprism. As in the molecules previously discussed, the nitrogen atoms attain $\mathrm{cn}=5$; again mostly ionic interactions between the lithium and nitrogen atoms have to be considered to explain these unusual high coordination numbers.

Arrangements of atoms within a cube have been found for a couple of compounds as can be seen from Table II. In $(\mathrm{AlH})_{3}(\mathrm{~N}-t-\mathrm{Bu})_{4} \mathrm{Mg} \cdot \mathrm{THF}$ and $(\mathrm{AlH})_{3}(\mathrm{~N}-$ $t$ - $\mathrm{Bu})_{4} \mathrm{Ca} \cdot 3 \mathrm{THF}$ the magnesium and calcium atoms (Figure 6C) replace an $\mathrm{AlH}$ group in a typical iminoalane, $(\mathrm{AlH})_{4}(\mathrm{~N}-t-\mathrm{Bu})_{4}$ (see section III.B.2). The smaller $\mathrm{Mg}$ atom is coordinated only by one THF molecule whereas the larger $\mathrm{Ca}$ atom has three THF molecules as additional ligands. In $(\mathrm{MeSi})_{2}(\mathrm{~N}-t-\mathrm{Bu})_{4} \mathrm{Li}_{2}$ the lithium atoms are threefold coordinated by nitrogen atoms and are located in the corners of the cube (Figure $6 \mathrm{D})$. Replacing these lithium atoms by magnesium methyl does not change the structure of the cage as can be seen for $(\mathrm{MeSi})_{2}(\mathrm{~N}-t-\mathrm{Bu})_{4}(\mathrm{MgMe})_{2}$.

Trigonal bipyramids are the common arrangements of the metal and nonmetal elements in a number of compounds of Table II. In $\mathrm{Si}_{2}(\mathrm{~N}-t-\mathrm{Bu})_{6} \mathrm{Li}_{4} \cdot 4 \mathrm{THF}$ two
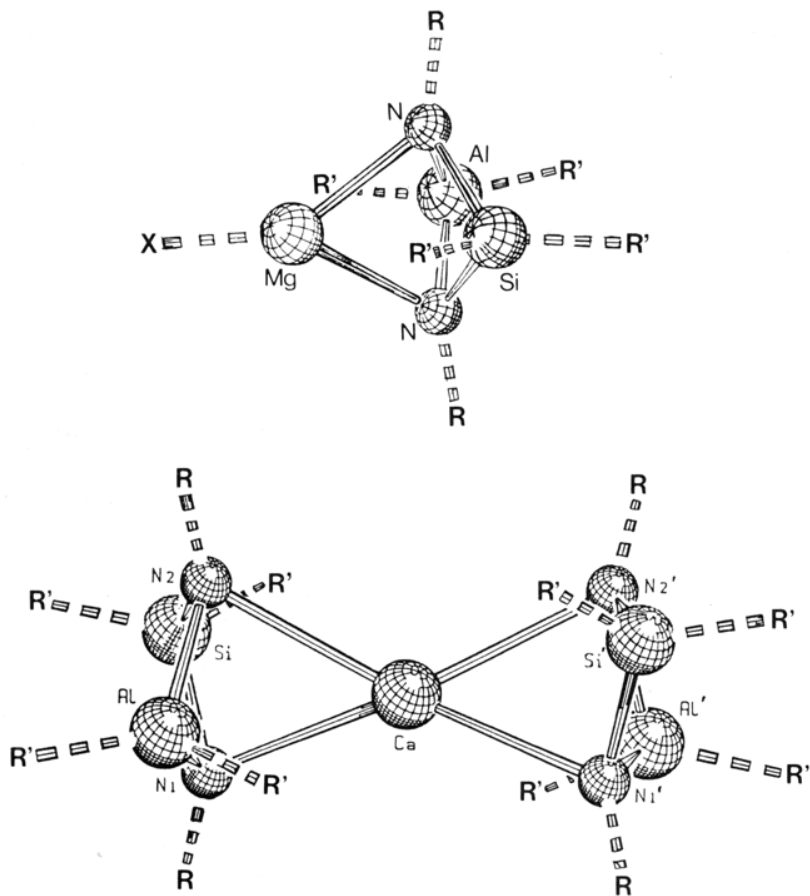

Figure 8. The cage core of $\left(\mathrm{Me}_{2} \mathrm{Si}\right)\left(\mathrm{Me}_{2} \mathrm{Al}\right)(\mathrm{XMg})(\mathrm{N}-t-\mathrm{Bu})_{2}(\mathrm{X}$ $\left.=\mathrm{N}\left(\mathrm{SiMe}_{3}\right)_{2}\right)$ and the structure of $\left[\left(\mathrm{Me}_{2} \mathrm{Si}\right)\left(\mathrm{Me}_{2} \mathrm{Al}\right) \mathrm{N}-t-\mathrm{Bu}_{2}\right]_{2} \mathrm{Ca}$ ( $\mathrm{R}$ stands for $t-\mathrm{Bu}, \mathrm{R}^{\prime}$ for $\mathrm{Me}$ ). ${ }^{54,55}$

$\mathrm{SiN}_{2} \mathrm{Li}_{2}$ cages (silicon and the two lithium atoms being placed in the equatorial corners of a trigonal bipyramid) are held together by an $\mathrm{Si}_{2} \mathrm{~N}_{2}$ four-membered ring (Figure 6E). While the nitrogen atoms have tert-butyl groups as additional ligands, the lithium atoms are coordinated by THF, lithium attaining a coordination number of 3 within the $\mathrm{N}_{2} \mathrm{O}$ plane. In $\left(\mathrm{Me}_{2} \mathrm{Si}\right)$ $\left(\mathrm{Me}_{2} \mathrm{Al}\right)(\mathrm{MgX})(\mathrm{N}-t-\mathrm{Bu})_{2} \mathrm{Mg}, \mathrm{Al}$, and $\mathrm{Si}$ are disposed in a plane and coordinated pyramidally by two nitrogen atoms, thus forming a $\mathrm{N}_{2} \mathrm{MgAlSi}$ bipyramid (Figures $6 \mathrm{~F}$ and 8). If $\mathrm{X}=\mathrm{I}$ a dimeric structure is found through intermolecular Mg...I contacts, ${ }^{53}$ while in the compound with $\mathrm{X}=\mathrm{N}\left(\mathrm{SiMe}_{3}\right)_{2}$ the magnesium atom has the unique coordination number of 3 . It is almost in a plane of three nitrogen atoms and has an extremely short $\mathrm{Mg}-\mathrm{N}$ bond to the nitrogen atom of the hexamethyldisilazyl group (1.936 (6) $\AA$ ). In [( $\left.\mathrm{Me}_{2} \mathrm{Si}\right)$ $\left.\left(\mathrm{Me}_{2} \mathrm{Al}\right)(\mathrm{N}-t-\mathrm{Bu})_{2}\right]_{2} \mathrm{Ca}$ two $\mathrm{SiAlN}_{2} \mathrm{Ca}$ trigonal bipyramids are intersecting at the common calcium atom, which by the way attains a fourfold coordination (Figures $6 \mathrm{G}$ and 8 ).

\section{Iminoalanes and Related Cages}

In a recent review by Cesari and Cucinella the chemistry and structural chemistry of iminoalanes have been described exhaustively. ${ }^{56}$ We therefore restrict ourselves in this section to the discussion of some essential features in comparison to the other cages described in this article. The syntheses of the compounds can be performed by various routes, the two depicted in eq 3 and 4 being the most important.

$$
\begin{aligned}
& \mathrm{AlR}_{3}+\mathrm{H}_{2} \mathrm{~N}-\mathrm{R}^{\prime} \underset{-\mathrm{RH}}{\longrightarrow} 1 / n\left(\mathrm{R}_{2} \mathrm{Al}-\mathrm{NHR}^{\prime}\right)_{n} \underset{-\mathrm{RH}}{\stackrel{\Delta T}{\longrightarrow}} \\
& 1 / m\left(\mathrm{RAlNR}^{\prime}\right)_{m} \\
& \text { iminoalane } \\
& \mathrm{LiAlH}_{4}+\mathrm{RNH}_{3} \mathrm{Cl} \rightarrow \frac{1}{m}(\mathrm{HAlNR})_{m}+3 \mathrm{H}_{2}+\mathrm{LiCl}
\end{aligned}
$$


TABLE III. Iminoalanes and Related Cages

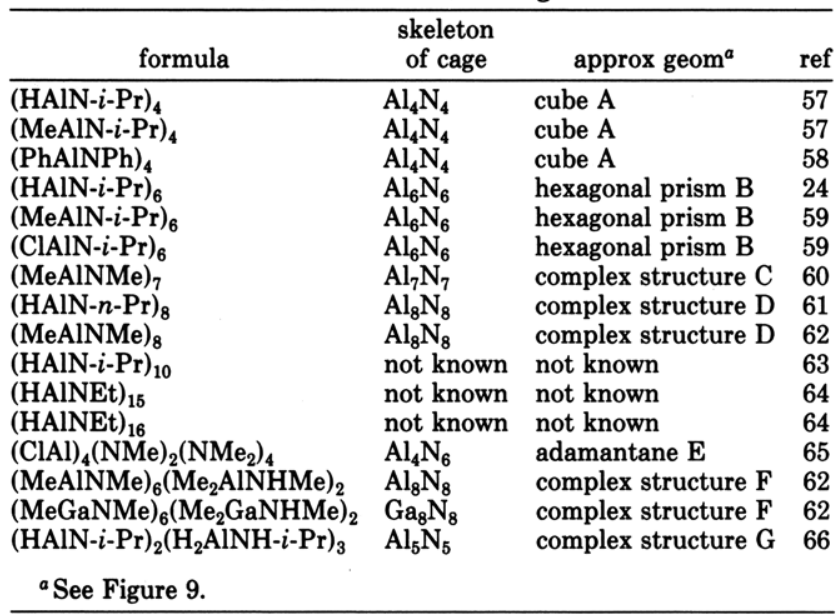

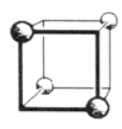

ค

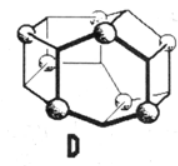

D

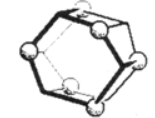

B
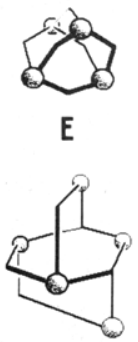

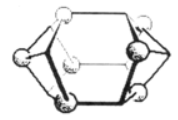

C

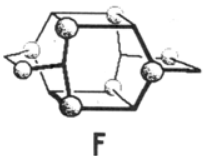

Figure 9. Cages found in the iminoalane series (see also Figure 2).

In Table III some iminoalanes and related cages are assembled. Representations of their structures are collected in Figure 9. As can be seen the degree of oligomerization for the pure iminoalanes ranges from 4 to 16 . X-ray structure analyses have been performed on the tetramers up to the octamers. An almost perfect cubic arrangement (angles at $\mathrm{Al}$ and $\mathrm{N}: 90 \pm 1^{\circ}$, Figure $9 \mathrm{~A}$ ) is independent of the nature of the substituents on the aluminum and nitrogen atoms. The hexamers form $\mathrm{Al}_{6} \mathrm{~N}_{6}$ hexagonal prisms with alternation of metals and nonmetals (Figure 9B). The four-membered sides of these prisms have $\mathrm{N}-\mathrm{Al}-\mathrm{N}$ angles of $91.2(2)^{\circ}$ and $\mathrm{Al}-$ $\mathrm{N}-\mathrm{Al}$ angles of $88.6(1)^{\circ}$, while the "hexagon" has $\mathrm{N}-$ $\mathrm{Al}-\mathrm{N}$ angles of $115.7(7)^{\circ}$ and $\mathrm{Al}-\mathrm{N}-\mathrm{Al}$ angles of 123.8 (6) ${ }^{\circ}$. The only significantly distorted cage of this hexamer series is (ClAlN-i-Pr) $)_{6}$. The heptamer (MeAlN$\mathrm{Me})_{7}$ forms a cage that can be generated by two $\mathrm{Al}_{4} \mathrm{~N}_{4}$ cubes, one cube omitting an aluminum atom and the other cube omitting a nitrogen atom, resulting in a 14-atom cage (Figure 9C). The higher oligomers $(\mathrm{MeAlNMe})_{8}$ and (HAlN- $\left.n-\mathrm{Pr}\right)_{8}$ have a cage skeleton in common, which arises by combining two $\mathrm{Al}_{4} \mathrm{~N}_{4}$ cubes, two edges of these cubes being broken and recombined with the other counterpart (Figure 9D). The decamer, pentadecamer, and hexadecamer of Table III have not yet been the subjects of X-ray structure determinations.

In Table III four other compounds have been assembled that are not iminoalanes but that are closely related to them. The core of the compound $(\mathrm{ClAl})_{4^{-}}$
TABLE IV. Iminogermylenes, Iminostannylenes, Iminoplumbylenes, and Related Cages

\begin{tabular}{clll}
\hline formula & $\begin{array}{c}\text { skeleton } \\
\text { of cage }\end{array}$ & $\begin{array}{c}\text { approx } \\
\text { geom }\end{array}$ & \multicolumn{1}{c}{ ref } \\
\hline$(t \text {-BuN })_{4} \mathrm{Ge}_{4}$ & $\mathrm{Ge}_{4} \mathrm{~N}_{4}$ & cube & 69 \\
$(t-\mathrm{BuN})_{4} \mathrm{Sn}_{4}$ & $\mathrm{Sn}_{4} \mathrm{~N}_{4}$ & cube & 70,21 \\
$(t \text {-BuN })_{4} \mathrm{~Pb}_{4}$ & $\mathrm{~Pb}_{4} \mathrm{~N}_{4}$ & cube & 69 \\
$(t-\mathrm{BuN})_{4} \mathrm{Ge}_{3} \mathrm{Sn}$ & $\mathrm{Ge}_{3} \mathrm{SnN}_{4}$ & cube & 69 \\
$(t-\mathrm{BuN})_{4} \mathrm{Sn}_{2} \mathrm{~Pb}_{2}$ & $\mathrm{Sn}_{2} \mathrm{~Pb}_{2} \mathrm{~N}_{4}$ & cube & 69 \\
$\left(\mathrm{Me} \mathrm{NN}_{4}\right)_{4} \mathrm{Sn}_{4}$ & $\mathrm{Sn}_{4} \mathrm{~N}_{4}$ & cube & 71 \\
$(i-\mathrm{PrN})_{4} \mathrm{Sn}_{4}$ & $\mathrm{Sn}_{4} \mathrm{~N}_{4}$ & cube & 71 \\
$(\mathrm{PhN})_{4} \mathrm{Sn}_{4}$ & $\mathrm{Sn}_{4} \mathrm{~N}_{4}$ & cube & 72 \\
$(t \text {-BuN })_{3} \mathrm{OSn}_{4}$ & $\mathrm{Sn}_{4} \mathrm{~N}_{3} \mathrm{O}$ & cube & 73,21 \\
$(t \text {-BuN })_{3} \mathrm{SSn}_{4}$ & $\mathrm{Sn}_{4} \mathrm{~N}_{3} \mathrm{~S}$ & cube & 74 \\
${ }^{a} \mathrm{See} \mathrm{Figure} 10$. & & & \\
\hline
\end{tabular}

$(\mathrm{NMe})_{2}\left(\mathrm{NMe}_{2}\right)_{4}$ is an $\mathrm{Al}_{4} \mathrm{~N}_{6}$ cage, which adopts an adamantane type structure (Figure $9 \mathrm{E}$ ). The structures of the molecules (MeAlNMe $)_{6}\left(\mathrm{Me}_{2} \mathrm{AlNHMe}\right)_{2}$ and $(\mathrm{MeGaNMe})_{6}\left(\mathrm{Me}_{2} \mathrm{GaNHMe}\right)_{2}$ can be derived from a hexagonal prism, two edges of this prism being broken in order to insert two $\left[\mathrm{Me}_{2} \mathrm{MNMeH}\right]$ bridges (Figure $9 F)$. Finally, (HAlN-i-Pr $)_{2}\left(\mathrm{H}_{2} \mathrm{AlNH}-i-\mathrm{Pr}\right)_{3}$ may be regarded as a derivative of the nonexisting pentamer (HAlN-i-Pr) . A six-membered $\mathrm{Al}_{3} \mathrm{~N}_{3}$ ring is bridged at the 1,4- and 2,5-positions by $\mathrm{H}_{2} \mathrm{AlNH}-i$-Pr in such a way that a closed sphere is created (Figure 9G).

In all the compounds of Table III the aluminum atom always attains fourfold coordination as do the nitrogen atoms to which it is bonded. The $\mathrm{Al}-\mathrm{N}$ bond distances are in the range $1.89-1.98 \AA$, values consistent with a bond order between a single two-center bond and a single donor-acceptor bond. ${ }^{56,19 b}$ As in the cages the atoms get very close to each other (shortest $\mathrm{Al}$... Al and $\mathrm{N}$... $\mathrm{N}$ distance $2.66 \AA$ ), $\mathrm{Al}$... $\mathrm{Al}$ interactions may be assumed. There is nevertheless no spectroscopic evidence for this. ${ }^{56}$

\section{Iminogermylenes, Iminostannylenes, Iminoplumbylenes, and Related Cages}

When the monomeric, cyclic bis(amino)germylenes, -stannylenes, and -plumbylenes are allowed to react with primary amines, inimo compounds of $\mathrm{Ge}(\mathrm{II}), \mathrm{Sn}-$ (II), and $\mathrm{Pb}$ (II) can be obtained as depicted in eq $5 .^{23}$

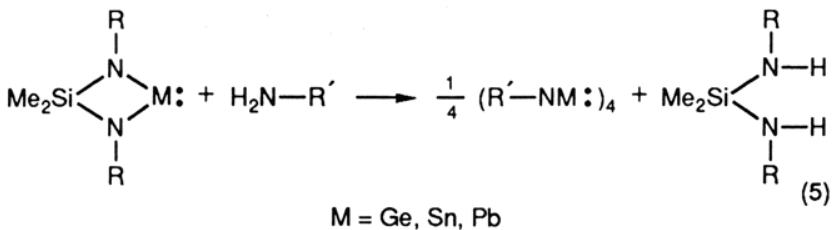

The mechanism of reaction 5 has been the subject of thorough investigations, and transient species as $\left\{\mathrm{R}^{\prime}-\right.$ $\mathrm{NM}$ :\}, which are heavier congeners of isocyanides, have been considered. ${ }^{67,68}$ The only kind of oligomer built up by this intermediate is the tetramer (compare previous section). With increasing weight of the low-valent element the activation energy in reaction 5 is lowered. ${ }^{69}$ In Table IV some representative examples of iminometal(II) compounds are listed. The ligand $\mathrm{R}^{\prime}$ at the nitrogen atom can be varied within a great range as found for the $\mathrm{Sn}_{4}\left(\mathrm{NR}^{\prime}\right)_{4}$ cages. If nevertheless its steric requirement is low, as for methyl and ethyl, a polymeric compound $\left(\mathrm{SnNR}^{\prime}\right)_{\infty}$ is formed. ${ }^{26}$ On the metal side, besides "homoatomic" arrangements, "heteroatomic" are also found. To synthesize these species, trans- 
TABLE V. Cages with Tl(I), Ge(II), Sn(II), N, and $\mathrm{O}$ as Main Components

\begin{tabular}{|c|c|c|c|}
\hline formula & $\begin{array}{c}\text { skeleton } \\
\text { of cage }\end{array}$ & approx geom ${ }^{a}$ & ref \\
\hline $\begin{array}{l}(\mathrm{MeSi})_{2}(\mathrm{~N}-t-\mathrm{Bu})_{4} \mathrm{Tl}_{2} \\
(\mathrm{MeSi})_{2}(\mathrm{~N}-t-\mathrm{Bu})_{6} \mathrm{Tl}_{6} \\
\left(\mathrm{Me} \mathrm{Te}_{2} \mathrm{Si}\right)(\mathrm{N}-t-\mathrm{Bu})_{2} \mathrm{Sn}_{2} \mathrm{X} \\
\quad\left(\mathrm{X}=\mathrm{N}-\mathrm{R}, \mathrm{O}, \mathrm{Cl}^{+}, \mathrm{Br}^{+}\right)\end{array}$ & $\begin{array}{l}\mathrm{Si}_{2} \mathrm{Tl}_{2} \mathrm{~N}_{4} \\
\mathrm{Si}_{2} \mathrm{~N}_{4} \mathrm{Tl}_{6} \\
\mathrm{SiN}_{2} \mathrm{Sn}_{2} \mathrm{X}\end{array}$ & $\begin{array}{l}\text { cube A } \\
\text { complex structure B } \\
\text { tetrahedron with two bridged edges C }\end{array}$ & $\begin{array}{l}50 \\
75 \\
70,76,77\end{array}$ \\
\hline$\left(\mathrm{Me}_{2} \mathrm{Si}\right)(\mathrm{NMe})_{5} \mathrm{Sn}_{4}$ & $\mathrm{SiN}_{5} \mathrm{Sn}_{4}$ & basketane-like D & 78 \\
\hline$(\mathrm{MeSi})(\mathrm{N}-t-\mathrm{Bu})_{3} \mathrm{Sn}_{3} \mathrm{O}^{+}$ & $\mathrm{SiN}_{3} \mathrm{Sn}_{3} \mathrm{O}$ & cube $\mathrm{E}$ & 75 \\
\hline $\begin{array}{l}(t-\mathrm{BuN})_{4} \mathrm{M}_{3} \mathrm{H}_{3} \mathrm{X}(\mathrm{M}=\mathrm{Ge}, \mathrm{X}=\mathrm{Cl} \\
\mathrm{M}=\mathrm{Sn}, \mathrm{X}=\mathrm{Cl} ; \mathrm{M}=\mathrm{Sn}, \mathrm{X}=\mathrm{Br} \\
\mathrm{M}=\mathrm{Sn}, \mathrm{X}=\mathrm{I})\end{array}$ & $\mathrm{M}_{3} \mathrm{H}_{4} \mathrm{H}_{3} \mathrm{X}$ & complex structure $\mathrm{E}$ & 74 \\
\hline$(t-\mathrm{BuN})_{2}(t-\mathrm{BuO})_{2} \mathrm{Sn}_{3}$ & $\mathrm{Sn}_{3} \mathrm{~N}_{2} \mathrm{O}_{2}$ & two face-connected trigonal bipyramids $\mathrm{G}$ & 79 \\
\hline$(t-\mathrm{BuN})_{2}(t-\mathrm{BuO})_{2} \mathrm{Ge}_{2} \mathrm{Sn}$ & $\mathrm{SnGe}_{2} \mathrm{~N}_{2} \mathrm{O}_{2}$ & two face-connected trigonal bipyramids $\mathrm{G}$ & 79 \\
\hline$\left(\mathrm{Me}_{2} \mathrm{Si}\right)_{3}(\mathrm{NMe})_{5} \mathrm{Sn}_{2}$ & $\mathrm{Si}_{3} \mathrm{~N}_{5} \mathrm{Sn}_{2}$ & tetrahedron with two opposite three-membered loops $\mathrm{H}$ & 78 \\
\hline \multicolumn{4}{|l|}{${ }^{a}$ See Figure 11.} \\
\hline
\end{tabular}
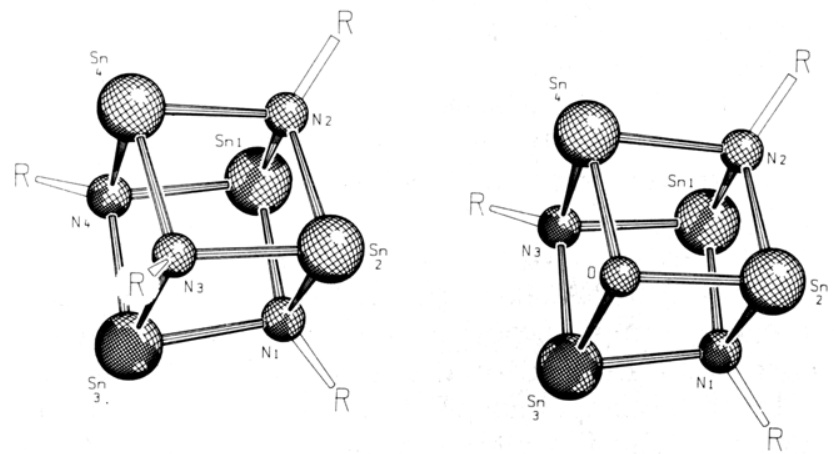

Figure 10. The cores of iminostannylenes $(t-B u N S n)_{4}$ and $(t-$ $\mathrm{BuN})_{3} \mathrm{OSn}_{4}$ as determined by X-ray structure investigations. ${ }^{21}$

amination reactions can be used (eq 6) as well as scrambling reactions (eq 7), which work well if lead is present in the educts. Also on the nonmetal site a mixture of different elements may be obtained as in the compounds $(t-\mathrm{BuN})_{3} \mathrm{XSn}_{4}(\mathrm{X}=\mathrm{O}, \mathrm{S})$, which are synthesized according to route (8).

$$
\begin{gathered}
(t-\mathrm{BuN})_{2}(t-\mathrm{BuNH})_{2} \mathrm{M}_{3}^{\prime}+\mathrm{Me}_{2} \mathrm{Si}(\mathrm{NR})_{2} \mathrm{M} \rightarrow \\
(t-\mathrm{BuN})_{4} \mathrm{M}_{3}^{\prime} \mathrm{M}+\mathrm{Me}_{2} \mathrm{Si}(\mathrm{N}(\mathrm{R}) \mathrm{H})_{2} \\
\mathrm{M}, \mathrm{M}^{\prime}=\mathrm{Ge}, \mathrm{Sn}, \mathrm{Pb}
\end{gathered}
$$$$
9(t-\mathrm{BuN})_{4} \mathrm{Sn}_{3} \mathrm{~Pb} \stackrel{\Delta T}{\longrightarrow} 6(t-\mathrm{BuN})_{4} \mathrm{Sn}_{4}+
$$$$
(t-\mathrm{BuN})_{4} \mathrm{Sn}_{2} \mathrm{~Pb}_{2}+(t-\mathrm{BuN}){ }_{4} \mathrm{SnPb}_{3}+(t-\mathrm{BuN})_{4} \mathrm{~Pb}_{4}
$$

$$
\begin{aligned}
2(t-\mathrm{BuN})_{2}(t-\mathrm{BuNH})_{2} \mathrm{Sn}_{3} \stackrel{+\mathrm{XH}_{2}}{\longrightarrow}\left(t-\mathrm{BuN}_{3} \mathrm{XSn}_{4}+3 t-\mathrm{BuNH}_{2}\right. \\
\mathrm{X}=\mathrm{O}, \mathrm{S}
\end{aligned}
$$

In Figure 10 the structures of the cages $(t-\mathrm{BuN})_{4} \mathrm{Sn}_{4}$ and $(t-\mathrm{BuN})_{3} \mathrm{OSn}_{4}$ are depicted. The distortion of the cubes has been discussed already in section II.B. As far as the $\mathrm{Sn}-\mathrm{N}$ bond distances are concerned, they are almost constant in these two structures as well as in $(t-\mathrm{BuN})_{3}\left(\mathrm{Cl}_{3} \mathrm{AlO}\right) \mathrm{Sn}_{4}{ }^{75}$ and $(t-\mathrm{BuN})_{3} \mathrm{SSn}_{4}{ }^{74}$ ranging from 2.202 to $2.220 \AA$. The bond lengths can be attributed to a single bond, which has two-thirds of a normal single-bond distance and one-third of a donoracceptor bond distance. ${ }^{21}$ The tin atoms within their tetrahedral subarrangement have contacts of 3.321-3.348 $\AA$, while the nitrogen atoms come as close together as $2.87 \AA$ (a value that is $\sim 0.20 \AA$ longer than in the comparable iminoalanes). There is no experimental evidence for a strong metal-metal interaction within these cages. ${ }^{23}$

\section{Cages with $T((I), G e(I I), S n(I I)$, Nitrogen, and Oxygen as Main Components}

The compounds assembled in Table $\mathrm{V}$ have been synthesized by two different approaches. One objective has been to trap an unsaturated metal/nonmetal arrangement by another fragment of opposite polarity, as is largely explained in a recent review. ${ }^{23}$ In eq 9 , for example, the unstable iminostannylene $(t \text {-BuNSn })_{2}$, which through reaction with itself usually dimerizes to give the tetramer (see before), is trapped by di-tertbutoxytin(II) to form $(t-\mathrm{BuN})_{2}(t-\mathrm{BuO})_{2} \mathrm{Sn}_{3}$. In a similar way, transient $\{\mathrm{SnX}\}$ can be trapped by $\mathrm{Me}_{2} \mathrm{Si}(\mathrm{N}-t$ $\mathrm{Bu})_{2} \mathrm{Sn}$ (eq 10); the norcubane-like molecules ( $t$ $\mathrm{BuN})_{2}(t-\mathrm{BuNH})_{2} \mathrm{Ge}_{3}$ and $(t-\mathrm{BuN})_{2}(t-\mathrm{BuNH})_{2} \mathrm{Sn}_{3}$ can also trap gaseous hydrohalogens (eq 11).

$$
\begin{gathered}
\left\{(t-\mathrm{BuNM})_{2}\right\}+\frac{1}{2}\left[\mathrm{Sn}(\mathrm{O}-t-\mathrm{Bu})_{2}\right]_{2} \rightarrow \\
\quad(t-\mathrm{BuN})_{2}(t-\mathrm{BuO})_{2} \mathrm{M}_{2} \mathrm{Sn}(9) \\
\mathrm{M}=\mathrm{Ge}, \mathrm{Sn} \\
\mathrm{Me}_{2} \mathrm{Si}(\mathrm{N}-t-\mathrm{Bu})_{2} \mathrm{Sn}+\mathrm{SnX} \rightarrow \mathrm{Me}_{2} \mathrm{Si}(\mathrm{N}-t-\mathrm{Bu})_{2} \mathrm{Sn}_{2} \mathrm{X}
\end{gathered}
$$

$$
\mathrm{X}=\mathrm{NR}, \mathrm{O}, \mathrm{Cl}^{+}, \mathrm{Br}^{+}
$$

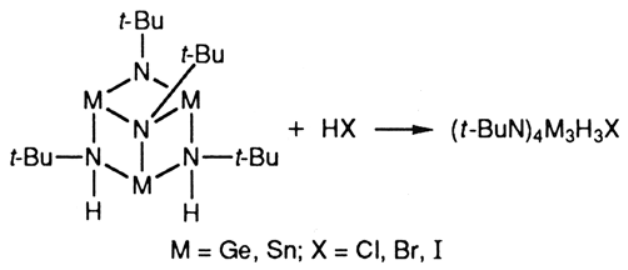

The other molecules from Table $\mathrm{V}$ are obtained starting from lithium derivatives of special silazanes (see also section III.B.1) by displacement of the lithium by the subvalent elements Tl(I), Ge(II), and $\mathrm{Sn}(\mathrm{II})$ and formation of lithium chloride. The cages arise from intramolecular bonds between the unsaturated metals and the nitrogen or oxygen atoms acting as electron donors (eq 12-14).

$$
\begin{aligned}
& x \mathrm{Me}_{2} \mathrm{Si}(\mathrm{NMe})_{2} \mathrm{Li}_{2} \underset{-\mathrm{LiCl}}{\stackrel{y \mathrm{SnCl}_{2}}{\longrightarrow}} \\
& \mathrm{Me}_{2} \mathrm{Si}(\mathrm{NMe})_{5} \mathrm{Sn}_{4}+\left(\mathrm{Me}_{2} \mathrm{Si}\right)_{3}(\mathrm{NMe})_{5} \mathrm{Sn}_{2}
\end{aligned}
$$




$$
\begin{aligned}
\frac{1}{2}\left[\mathrm{MeSi}(\mathrm{N}-t-\mathrm{BuLi})_{3}\right]_{2} & \stackrel{+4 \mathrm{SnCl}_{2}, \mathrm{OH}_{2}}{-3 \mathrm{LiCl}_{2}-2 \mathrm{HCl}} \\
(\mathrm{MeSi})(\mathrm{N}-t-\mathrm{Bu})_{3} \mathrm{OSn}_{3}{ }^{+} \mathrm{SnCl}_{3}{ }^{-}(13 \mathrm{a}) & \\
{\left[\mathrm{MeSi}(\mathrm{N}-t-\mathrm{BuLi})_{3}\right]_{2} } & \stackrel{+3 \mathrm{TICl}}{\underset{-3 \mathrm{LiCl}}{\longrightarrow}}\left[(\mathrm{MeSi})(\mathrm{N}-t-\mathrm{Bu})_{3} \mathrm{Tl}_{3}\right]_{2}
\end{aligned}
$$

$$
(\mathrm{MeSi})_{2}(\mathrm{~N}-t-\mathrm{Bu})_{4} \mathrm{Li}_{2} \underset{-2 \mathrm{LiCl}}{\stackrel{+2 \mathrm{TlCl}}{\longrightarrow}}(\mathrm{MeSi})_{2}(\mathrm{~N}-t-\mathrm{Bu})_{4} \mathrm{Tl}_{2}
$$

In Figure 11 the three-dimensional atom skeletons within the cages are sketched. The two thallium compounds should be compared with their lithium analogues (section III.B.1). Whereas the cube arrangement of $\mathrm{Si}_{2} \mathrm{Tl}_{2} \mathrm{~N}_{4}$ in $(\mathrm{MeSi})_{2}(\mathrm{~N}-t-\mathrm{Bu})_{4} \mathrm{Tl}_{2}$ (Figure 11A) resembles the corresponding lithium compound in gross structural features (the distortion of the cube is more important in the thallium derivative because of the greater atomic radius of $\mathrm{Tl})$, the structure of $(\mathrm{MeSi})_{2}$ $(\mathrm{N}-t-\mathrm{Bu})_{6} \mathrm{Tl}_{6}$ is remarkably different from that of the lithium derivative (Figure 7A,B). A very short Tl-Tl distance of $3.165 \AA$ is observed, which is much shorter than the other distances ranging from 3.46 to $3.92 \AA$ and which has to be considered as a bonding interaction. Because of this interaction the cage loses the $\overline{3}\left(S_{6}\right)$ symmetry element, which can be attributed to the "free" lithium compound, and only the symmetry of inversion $\overline{1}\left(C_{i}\right)$ is retained. The structure of the $\mathrm{Si}_{2} \mathrm{~N}_{6} \mathrm{Tl}_{6}$ cage can be described as two $\mathrm{SiN}_{3} \mathrm{Tl}_{4}$ cubes fused at a common $\mathrm{Tl}_{2}$ edge (see Figures $7 \mathrm{~B}$ and $11 \mathrm{~B}$ ). A cube is also found to be the core of the cation $(\mathrm{MeSi})(\mathrm{N}-t$ $\mathrm{Bu})_{3} \mathrm{Sn}_{3} \mathrm{O}^{+}$. It can be compared with $\mathrm{Sn}_{4}(\mathrm{~N}-t-\mathrm{Bu})_{3} \mathrm{O}$, a $\mathrm{Sn}(\mathrm{II})$ atom being formally replaced by $\mathrm{MeSi}^{+}$.

The molecules $\mathrm{Me}_{2} \mathrm{Si}(\mathrm{N}-t-\mathrm{Bu})_{2} \mathrm{Sn}_{2} \mathrm{X}(\mathrm{X}=\mathrm{NR}, \mathrm{O})$ and the isoelectronic cations $\left(\mathrm{X}=\mathrm{Cl}^{+}, \mathrm{Br}^{+}\right.$, the charge on the halogens being only formal) have an isostructural cage in common. This cage can be deduced from an $\mathrm{Sn}_{2} \mathrm{~N}_{2}$ tetrahedron, two opposite edges being capped by the dimethylsilyl group and the atom $\mathrm{X}$ (Figure 11C). The $\mathrm{Sn}-\mathrm{N}$ bond lengths within the cage are alike and are in a range from 2.227 to $2.33 \AA$ for the four compounds characterized so far by X-ray structure determinations (for references see Table V). The tin atoms are at the top of a trigonal $\mathrm{N}_{2} \mathrm{SnX}$ pyramid (the N$\mathrm{Sn}-\mathrm{N}$ angles being extremely acute $\left(62-64^{\circ}\right)$ ) while the nitrogen atoms are tetrahedrally (distorted) coordinated.

A very rare seven-membered atomic cage is characteristic of the molecules $(t-\mathrm{BuN})_{2}(t-\mathrm{BuO})_{2} \mathrm{Sn}_{3}$ and $(t$ $\mathrm{BuN})_{2}(t-\mathrm{BuO})_{2} \mathrm{Ge}_{2} \mathrm{Sn}$ : two $\mathrm{M}_{2} \mathrm{ON}_{2}$ trigonal bipyramids are connected via their $\mathrm{MN}_{2}$ faces (Figure $11 \mathrm{G}$ ). Whereas the connecting metal atom (Sn in both cases) has a coordination number of 4 , the other two (Ge and Sn, respectively) have the typical pyramidal environment. The nitrogen atoms in the two compounds have four neighbors and the oxygen atoms three, being almost in a plane with the bonding atoms.

Another very peculiar cage system is found in the compounds $(t-\mathrm{BuN})_{4} \mathrm{M}_{3} \mathrm{H}_{3} \mathrm{X}$. The cage can be described starting with an $\mathrm{Sn}_{3} \mathrm{~N}_{4} \mathrm{X}$ cube, the corner $\mathrm{X}$ being drawn off the center along the threefold diagonal by inserting three hydrogen atoms in between the corner $\mathrm{X}$ and the neighboring corners $\mathrm{N}$ (Figure 11F). The hydrogen atoms thus have $\mathrm{cn}=2$ and the halogen atom is threefold coordinated (trigonal pyramid with

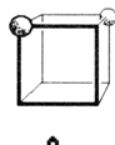

ค

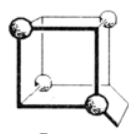

D
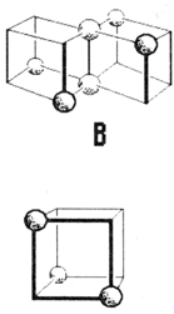

$\mathrm{E}$
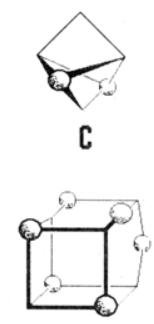

$\mathrm{F}$

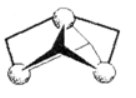

G

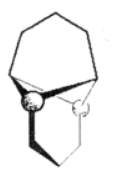

H
Figure 11. Cages with miscellaneous nonmetal elements. The silicon, halogen, nitrogen, and oxygen atoms are represented as corners; the locations of the metals and hydrogen atoms are represented with balls.

an $\mathrm{H}-\mathrm{Cl}-\mathrm{H}$ angle of about $60^{\circ}$ ). In the two compounds structurally characterized, $\mathrm{Ge}_{3}(\mathrm{~N}-t-\mathrm{Bu})_{4} \mathrm{H}_{3} \mathrm{Cl}$ and $\mathrm{Sn}_{3}$ $(\mathrm{N}-t-\mathrm{Bu})_{4} \mathrm{H}_{3} \mathrm{Cl}$, the $\mathrm{H}-\mathrm{Cl}$ distances are in the range of $2.36-2.38 \AA((\mathrm{N}-\mathrm{H}=0.96 \AA)$. These values are typical for $\mathrm{N}-\mathrm{H} \ldots \mathrm{Cl}$ bridges (in $\mathrm{Me}_{3} \mathrm{NHCl}, \mathrm{N} \ldots \mathrm{Cl}=3.00 \AA^{80}$ ). Furthermore, we feel that besides hydrogen bridging also an intramolecular charge distribution of the type $\mathrm{M}_{3}(\mathrm{~N}-t-\mathrm{Bu})_{4} \mathrm{H}_{3}{ }^{+} \mathrm{Cl}^{-}$has to be considered.

The two ten-membered cages obtained in reaction 12 are again quite remarkable. The molecule $\left(\mathrm{Me}_{2} \mathrm{Si}\right)$ $(\mathrm{NMe})_{5} \mathrm{Sn}_{4}$ is an inorganic analogue of the well-known "basketane": 81 in one $\mathrm{Sn}-\mathrm{N}$ edge of an $\mathrm{Sn}_{4} \mathrm{~N}_{4}$ cube the loop $\mathrm{Me}_{2} \mathrm{SiNMe}$ is inserted forming the handle at the $\mathrm{Sn}_{4} \mathrm{~N}_{4}$ basket (Figure 11D). The other reaction product may be generated from this basketane analogue by formally replacing two of the tin atoms by dimethylsilyl groups. As fewer metals (fewer electrophilic centers) are present in the molecule $\left(\mathrm{Me}_{2} \mathrm{Si}\right)_{3}(\mathrm{NMe})_{5} \mathrm{Sn}_{2}$, the structure is completely changed: an $\mathrm{Sn}_{2} \mathrm{~N}_{2}$ tetrahedron is bridged at two opposite edges by $(\mathrm{NMe})\left(\mathrm{SiMe}_{2}\right)$ $(\mathrm{NMe})$ or $\left(\mathrm{Me}_{2} \mathrm{Si}\right)(\mathrm{NMe})\left(\mathrm{SiMe}_{2}\right)$ loops (Figure $\left.11 \mathrm{H}\right)$.

\section{Metal Alkoxides}

\section{Cages Formed by Metal Alkoxides and Related Compounds}

Following the principles developed mainly by Bradley and Mehrotra ${ }^{17}$ and exemplified in section II, we should find cage compounds in the metal alkoxides if two conditions are satisfied: (1) the metal should be low valent or should bear a low charge; (2) the substituent at the oxygen atom should be bulky.

As can be seen from the selection of metal alkoxides compiled in Table VI, the metallic part of the molecules consists of alkali metal elements, alkaline earth elements, or the heavy elements $\mathrm{Tl}(\mathrm{I})$ and $\mathrm{Pb}(\mathrm{II})$. With respect to the substituents at the oxygen atom, the tert-butyl group is very prominent. The smaller methyl group is found in $(\mathrm{MeMg})_{4}(\mathrm{OMe})_{4}$ and $\mathrm{Tl}_{4}(\mathrm{OMe})_{4}$. A great number of lithium enolates are known to form cage structures,$^{30}$ two of them being depicted in Table VI (see also section IV).

Metal alkoxides may be synthesized mainly by at least eight different routes, ${ }^{17}$ which are summarized by eqs $15 \mathrm{a}-\mathrm{h}$. 


$$
\begin{gathered}
\mathrm{M}+n \mathrm{ROH} \rightarrow \mathrm{M}(\mathrm{OR})_{n}+n / 2 \mathrm{H}_{2} \\
\mathrm{MCl}_{n}+n \mathrm{ROH} \rightarrow \mathrm{M}(\mathrm{OR})_{n}+n \mathrm{HCl} \\
\mathrm{MO}_{n}+2 n \mathrm{ROH} \rightarrow \mathrm{M}(\mathrm{OR})_{2 n}+n \mathrm{H}_{2} \mathrm{O} \\
\mathrm{M}(\mathrm{OR})_{n}+n \mathrm{R}^{\prime} \mathrm{OH} \rightarrow \mathrm{M}\left(\mathrm{OR}^{\prime}\right)_{n}+n \mathrm{ROH} \\
\mathrm{M}(\mathrm{OR})_{n}+x \mathrm{CH}_{3} \mathrm{COOR} \rightarrow \\
\mathrm{M}(\mathrm{OR})_{n-x}\left(\mathrm{OR}^{\prime}\right)_{x}+x \mathrm{CH}_{3} \mathrm{COOR} \\
\mathrm{M}\left(\mathrm{NR}_{2}\right)_{n}+n \mathrm{ROH} \rightarrow \mathrm{M}(\mathrm{OR})_{n}+n \mathrm{R}_{2} \mathrm{NH} \\
\mathrm{MCl}_{n}+n \mathrm{LiOR} \rightarrow \mathrm{M}(\mathrm{OR})_{n}+n \mathrm{LiCl}^{\prime} \\
\mathrm{MR}_{n}^{\prime}+n \mathrm{ROH} \rightarrow \mathrm{M}(\mathrm{OR})_{n}+n \mathrm{R}^{\prime} \mathrm{H}
\end{gathered}
$$

The reactivity of the metal, metal halide, metal oxide, or metal hydroxide with the alcohol as well as the alcohol interchange or the transesterification (eqs 15a-e) is limited with respect to the activity of the metal. In contrast the alcoholysis of metal amides (eq 15f), the salt reaction (eq $15 \mathrm{~g}$ ), and the alcoholysis of a metal alkyl are more generally applicable.

Besides pure metal alcoholates, we have assembled three representative examples of tin oxygen alkoxides, esters, and phosphates in Table VI. They have been included to demonstrate the resemblance with alkoxides, especially as far as the structures of the cages are concerned (see also a recent review ${ }^{82}$ ). Other very complicated cages with an oxygen-tin framework have been obtained recently by hydrolysis of monoorganotin trichlorides: $(i \text { - } \mathrm{PrSn})_{9} \mathrm{O}_{8}(\mathrm{OH})_{6} \mathrm{Cl}_{5}$ contains an $\mathrm{Sn}_{9} \mathrm{O}_{14}$ cage ${ }^{83 \mathrm{a}}$ and $\left[(i-\mathrm{PrSn})_{12} \mathrm{O}_{14}(\mathrm{OH})_{6}\right] \mathrm{Cl}_{2} \cdot 3 \mathrm{H}_{2} \mathrm{O}$ has an $\mathrm{Sn}_{12} \mathrm{O}_{20}$ cage, which resembles an "American football" as described by the authors. ${ }^{83 b}$

Whereas the methoxides of alkali metal elements ${ }^{84,16 a}$ and the isopropyl oxides of $\mathrm{K}, \mathrm{Rb}$, and $\mathrm{Cs}$ are polymeric, ${ }^{85}$ the tert-butoxy derivatives are oligomeric and form cage compounds. Lithium tert-butoxide seems to exist as a tetramer (which has presumably a cube structure) and a hexamer ${ }^{86}$ Lithium isopropyl oxide is claimed to be "molecular" with the formula ( $i$-PrO$\mathrm{Li}_{11}{ }^{86 \mathrm{a}} \mathrm{X}$-ray structure determinations of the two lithium enolates $\mathrm{Li}_{4}\left(\mathrm{OC}_{5} \mathrm{H}_{7}\right)_{4} \cdot 4 \mathrm{THF}$ (lithium cyclopentenoate) and $\mathrm{Li}_{4}(\mathrm{OC}(\mathrm{OMe}) \mathrm{CH}-t-\mathrm{Bu})_{4} \cdot 4 \mathrm{THF}$ show that both substances have a $\mathrm{Li}_{4} \mathrm{O}_{4}$ cube in common. The lithium atoms are coordinated by additional solvate molecules (THF) to give a distorted tetrahedron (Table VI and Figure 12B). The sodium tert-butoxide can be crystallized in a form that combines a hexameric and nonameric oligomer. As can be deduced from Figure $12 \mathrm{C}$, the $\mathrm{Na}_{6} \mathrm{O}_{6}$ cage is isostructural with the $\mathrm{Al}_{6} \mathrm{~N}_{6}$ iminoalane cage described in a previous section. In contrast, the $\mathrm{Na}_{3} \mathrm{O}_{3}$ six-membered ring is no longer planar. The nonamer $\mathrm{Na}_{9}(\mathrm{O}-t-\mathrm{Bu})_{9}$ has a $\mathrm{Na}_{9} \mathrm{O}_{9}$ core that can be derived from two almost parallel six-membered $\mathrm{Na}_{3} \mathrm{O}_{3}$ rings that are connected by three oxygen atoms and three sodium atoms in such a way that every oxygen atom is fourfold coordinated, whereas the sodium atoms have $\mathrm{cn}=3$ (Figure 12D). For the heavier metals of main-group I, $\mathrm{K}, \mathrm{Rb}$, and $\mathrm{Cs}$, the tert-butanolates and trimethylsilanolates are tetrameric with a $\mathrm{M}_{4} \mathrm{O}_{4}$ cube.

Alcoholates of alkaline earth elements are usually coordination polymers as has been found for the crystalline solids of methoxides and ethoxides of magnesium, calcium, strontium, and barium. ${ }^{92}$ The structures are nevertheless changed if noncoordinating substitu-

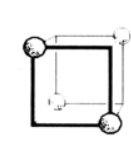

ค

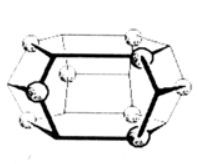

D

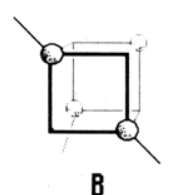

B

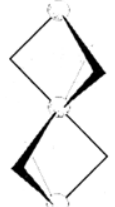

E

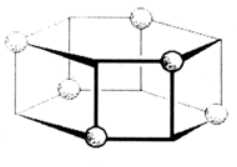

c

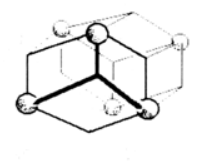

$\mathbf{F}$
Figure 12. Cages formed by metal alkoxides (see also Figure 2).
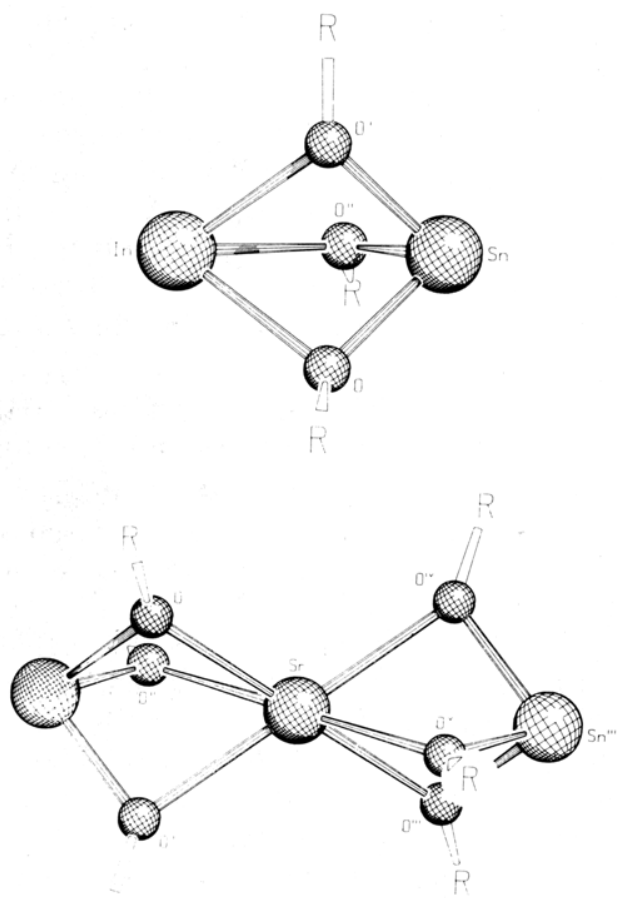

Figure 13. The cores of the molecules $\mathrm{Sn}(\mathrm{O}-t-\mathrm{Bu})_{3} \mathrm{Sr}(\mathrm{O}-t$ $\mathrm{Bu})_{3} \mathrm{Sn}^{104}$ and $\mathrm{Sn}(\mathrm{O}-t-\mathrm{Bu})_{3} \mathrm{In}^{101}$ as determined by X-ray structure investigations.

ents like organic groups are bound to the metal in addition to the alcoholate moieties. $(\mathrm{MeBe})_{4}\left(\mathrm{OSiMe}_{3}\right)_{4}$ and $(\mathrm{MeMg})_{4}(\mathrm{OMe})_{4}$ are definitely tetrameric and have a $\mathrm{M}_{4} \mathrm{O}_{4}$ cube as a common skeleton (see Table VI). As we have already discussed (see section II), thallium(I) methoxide is tetrameric.

Recently, we were able to synthesize lead di-tert-butoxide and solve its crystal structure. We found the compound to be trimeric. The $\mathrm{Pb}_{3} \mathrm{O}_{9}$ core can be described as two $\mathrm{Pb}_{2} \mathrm{O}_{3}$ trigonal bipyramids stuck together at a common $\mathrm{Pb}$ corner, the double cage adopting $\overline{3}\left(S_{6}\right)$ symmetry (Figure 12E). This structure is at first sight very astonishing, but nevertheless comprehensive since numerous examples of this structure type are found in the mixed metal(II) alkoxides of Ge(II), Sn(II), and $\mathrm{Pb}(\mathrm{II})$ (see next section and Figure 13). The peculiar isotropic environment of the central lead(II) (sixfold coordinated) is surprising and may be interpreted with a high motion (relatively high temperature factor) or an "inert" lone pair at the lead atom. ${ }^{95}$

In $\mathrm{Sn}_{6} \mathrm{O}_{4}(\mathrm{OMe})_{4}$, which can be obtained by hydrolysis of tin dimethoxide, six tin and four oxygen atoms are 
TABLE VI. Cages Derived from Some Selected Metal Alkoxides and Related Compounds

\begin{tabular}{|c|c|c|c|}
\hline formula & $\begin{array}{c}\text {-M skeleton } \\
\text { of cage }\end{array}$ & approx geom of cage ${ }^{b}$ & ref \\
\hline $\begin{array}{l}\mathrm{Li}_{4}(\mathrm{O}-t \cdot \mathrm{Bu})_{4} \\
\mathrm{Li}_{6}(\mathrm{O}-t-\mathrm{Bu})_{6} \\
\mathrm{Li}_{4}\left(\mathrm{OC}_{5} \mathrm{H}_{7}\right)_{4} \cdot 4 \mathrm{THF} \\
\mathrm{Li}_{4}[\mathrm{OC}(\mathrm{OMe}) \mathrm{CH}-t-\mathrm{Bu}]_{4} \\
\mathrm{Na}_{6}(\mathrm{O}-t-\mathrm{Bu})_{6} \\
\mathrm{Na}_{9}(\mathrm{O}-t-\mathrm{Bu})_{9} \\
\mathrm{M}_{4}(\mathrm{O}-t-\mathrm{Bu})_{4}(\mathrm{M}=\mathrm{K}, \mathrm{Rb}, \mathrm{Cs}) \\
\mathrm{M}_{4}(\mathrm{OSiMe})_{4}(\mathrm{M}=\mathrm{K}, \mathrm{Rb}, \mathrm{Cs}) \\
(\mathrm{MeBe})_{4}(\mathrm{OSiMe})_{4} \\
(\mathrm{MeMg})_{4}(\mathrm{OMe})_{4} \\
\mathrm{Tl}_{4}(\mathrm{OMe})_{4} \\
\mathrm{~Pb}_{3}(\mathrm{O}-t-\mathrm{Bu})_{9} \\
\mathrm{Sn}_{6} \mathrm{O}(\mathrm{OMe})_{4} \\
{\left[\mathrm{PhSn}(\mathrm{O}) \mathrm{O}_{2} \mathrm{CC} \mathrm{C}_{6} \mathrm{H}_{11}\right]_{6}} \\
{\left[n-\mathrm{BuSn}(\mathrm{O}) \mathrm{O}_{2} \mathrm{P}\left(\mathrm{C}_{6} \mathrm{H}_{11}\right)_{2}\right]_{4}}\end{array}$ & $\begin{array}{l}\mathrm{Li}_{4} \mathrm{O}_{4} \\
\text { unknown } \\
\mathrm{Li}_{4} \mathrm{O}_{4} \\
\mathrm{Li}_{4} \mathrm{O}_{4} \\
\mathrm{Na}_{6} \mathrm{O}_{6} \\
\mathrm{Na}_{9} \mathrm{O}_{9} \\
\mathrm{M}_{4} \mathrm{O}_{4} \\
\mathrm{M}_{4} \mathrm{O}_{4} \\
\mathrm{Be}_{4} \mathrm{O}_{4} \\
\mathrm{Mg}_{4} \mathrm{O}_{4} \\
\mathrm{Tl}_{4} \mathrm{O}_{4} \\
\mathrm{~Pb}_{3} \mathrm{O}_{9} \\
\mathrm{Sn}_{6} \mathrm{O}_{8} \\
\mathrm{Sn}_{6} \mathrm{O}_{6} \\
\mathrm{Sn}_{4} \mathrm{O}_{4}\end{array}$ & $\begin{array}{l}\text { cube A } \\
\text { unknown } \\
\text { cube B } \\
\text { cube B } \\
\text { hexagonal prism C } \\
\text { complex structure D } \\
\text { cube A } \\
\text { cube A } \\
\text { cube A } \\
\text { cube A } \\
\text { cube A } \\
\text { two trigonal bipyramids with common corner E } \\
\text { adamantane skeleton, capped at four sides F } \\
\text { hexagonal prism C } \\
\text { cube B }\end{array}$ & $\begin{array}{l}86 \\
86 \\
87 \\
88 \\
89 \\
89 \\
90 \\
91 \\
93 \\
94 \\
25 \\
95 \\
96 \\
97 \\
98\end{array}$ \\
\hline
\end{tabular}

TABLE VII. Cages Incorporating Ge(II), Sn(II), or Pb(II), Metal Alkoxides, and Main-Group Metals

\begin{tabular}{|c|c|c|c|}
\hline formula & $\begin{array}{c}\mathrm{C}-\mathrm{M} \text { skeleton } \\
\text { of cage }\end{array}$ & approx geom of cage ${ }^{a}$ & ref \\
\hline$\left[\mathrm{M}(\mathrm{O}-t-\mathrm{Bu})_{3} \mathrm{Sn}\right]_{\infty}(\mathrm{M}=\mathrm{K}, \mathrm{Rb}, \mathrm{Cs})$ & $\mathrm{SnO}_{3} \mathrm{M}$ & trigonal bipyramid & 100 \\
\hline $\mathrm{Ge}(\mathrm{O}-t-\mathrm{Bu})_{3} \mathrm{M}(\mathrm{M}=\mathrm{In}, \mathrm{Tl})$ & $\mathrm{GeO}_{3} \mathrm{M}$ & trigonal bipyramid & 101 \\
\hline $\mathrm{Sn}(\mathrm{O}-t-\mathrm{Bu})_{3} \mathrm{M}(\mathrm{M}=\mathrm{In}, \mathrm{Tl})$ & $\mathrm{SnO}_{3} \mathrm{M}$ & trigonal bipyramid & 101,102 \\
\hline $\mathrm{Pb}(\mathrm{O}-t-\mathrm{Bu})_{3} \mathrm{Tl}$ & $\mathrm{SnO}_{3} \mathrm{Tl}$ & trigonal bipyramid & 101 \\
\hline $\mathrm{Sn}(0-t-\mathrm{Bu})_{3} \mathrm{~Pb}^{+}$ & $\mathrm{SnO}_{3} \mathrm{~Pb}$ & trigonal bipyramid & 103 \\
\hline $\mathrm{Ge}(\mathrm{O}-t-\mathrm{Bu})_{3} \mathrm{M}(\mathrm{O}-t-\mathrm{Bu})_{3} \mathrm{Ge}(\mathrm{M}=\mathrm{Mg}, \mathrm{Ca}, \mathrm{Sr}, \mathrm{Ba}, \mathrm{Pb})$ & $\mathrm{GeO}_{3} \mathrm{Mo}_{3} \mathrm{Ge}$ & two trigonal bipyramids with a common corner & 103 \\
\hline $\mathrm{Sn}(\mathrm{O}-t-\mathrm{Bu})_{3} \mathrm{M}(\mathrm{O}-t-\mathrm{Bu})_{3} \mathrm{Sn}(\mathrm{M}=\mathrm{Ca}, \mathrm{Sr}, \mathrm{Ba}, \mathrm{Pb})$ & $\mathrm{SnO}_{3} \mathrm{Mo}_{3} \mathrm{Sn}$ & two trigonal bipyramids with a common corner & $103-105$ \\
\hline $\mathrm{Pb}(\mathrm{O}-t-\mathrm{Bu})_{3} \mathrm{M}(\mathrm{O}-t-\mathrm{Bu})_{3} \mathrm{~Pb}(\mathrm{M}=\mathrm{Ca}, \mathrm{Sr}, \mathrm{Ba})$ & $\mathrm{PbO}_{3} \mathrm{MO}_{3} \mathrm{~Pb}$ & two trigonal bipyramids with a common corner & 106 \\
\hline${ }^{a} \mathrm{Cf}$. Figure 13. & & & \\
\hline
\end{tabular}

displaced very similarly to the carbon atoms in adamantane. The four remaining methoxy groups always connect three tin atoms to generate a tetrahedron (see Figure $12 \mathrm{~F})$. In $\left[\mathrm{PhSn}(\mathrm{O}) \mathrm{O}_{2} \mathrm{CC}_{6} \mathrm{H}_{11}\right]_{6}$ the core of the molecule consists of six tin and six oxygen atoms in a hexagonal prismatic cage (idealized), the tin and oxygen atoms being alternately displaced. The other ligands (phenyl and $\mathrm{C}_{6} \mathrm{H}_{11} \mathrm{CO}_{2}$ ) complete the coordination of tin to a distorted octahedron. $\mathrm{A} \mathrm{Sn}_{4} \mathrm{O}_{4}$ cube is found in $\left[n-\mathrm{BuSn}(\mathrm{O}) \mathrm{O}_{2} \mathrm{P}\left(\mathrm{C}_{6} \mathrm{H}_{11}\right)_{2}\right]_{4}$ with four bridging phosphate groups between the metals, the tin again attaining a coordination of 6 .

\section{Cages Incorporating $\mathrm{Ge}(I I), \mathrm{Sn}(I I)$, or $\mathrm{Pb}(I I)$, Metal Alkoxides, and Main-Group Metals}

Tin(II) tert-butoxide is an excellent acid-base system $^{23}$ that can react with different metal alkoxides to form ternary compounds that consist of tin(II), alkoxide groups, and another metal. Presumably because of the steric requirements of the tert-butoxy groups, the products are often molecular and poorly coordinated. As an example, consider the direct interaction of tin(II) tert-butoxide with another metal alkoxide (eq 16a). Another mode of synthesis of mixed metal alkoxides involves salt elimination as shown in eq $16 \mathrm{~b}$.

$$
\begin{aligned}
& n(t-\mathrm{BuO})_{2} \mathrm{M}+\mathrm{M}^{\prime}(\mathrm{O}-t-\mathrm{Bu})_{n} \rightarrow\left(\mathrm{M}(\mathrm{O}-t-\mathrm{Bu})_{3}\right)_{n} \mathrm{M}^{\prime} \\
& \eta_{2}\left[\mathrm{M}(\mathrm{O}-t-\mathrm{Bu})_{3} \mathrm{Na}\right]_{2}+\mathrm{Cl}_{n} \mathrm{M}^{\prime} \rightarrow \\
& \left(\mathrm{M}(\mathrm{O}-t-\mathrm{Bu})_{3}\right)_{n} \mathrm{M}^{\prime}+n \mathrm{NaCl} \\
& \mathrm{M}=\mathrm{Ge}, \mathrm{Sn}, \mathrm{Pb} \\
& \mathrm{M}^{\prime}=\mathrm{K}, \mathrm{Rb}, \mathrm{Cs}, \operatorname{In}(\mathrm{I}), \mathrm{Tl}(\mathrm{I})(n=1) \\
& \mathrm{M}^{\prime}=\mathrm{Mg}, \mathrm{Ca}, \mathrm{Sr}, \mathrm{Ba}, \mathrm{Pb}(\mathrm{II})(n=2)
\end{aligned}
$$

In place of the tin(II) alkoxide or sodium alkoxystannate the corresponding germanium(II) and lead(II) compounds can be used.99 In Table VII the molecules obtained so far are listed in the usual way. As can be deduced from this table, no lithium and sodium derivatives are included, although they may be obtained as easily as the heavier homologues; ${ }^{100}$ they form dimers consisting of fused rings with fourfold-coordinated lithium and sodium atoms. In contrast to this, potassium, rubidium, and cesium tri-tert-butoxystannates have a $\mathrm{SnO}_{3} \mathrm{M}$ trigonal-bipyramidal skeleton, the alkali metal being further coordinated by two oxygen atoms of a second cage in the crystal. This gives a one-dimensional chain of trigonal bipyramids. Other compounds with a trigonal-bipyramidal cage are $\mathrm{Ge}(\mathrm{O}-\mathrm{t}$ $\mathrm{Bu})_{3} \mathrm{M}(\mathrm{M}=\mathrm{In}, \mathrm{Tl}), \mathrm{Sn}(\mathrm{O}-t-\mathrm{Bu})_{3} \mathrm{M}(\mathrm{M}=\mathrm{In}, \mathrm{Tl})$, and $\mathrm{Pb}(\mathrm{O}-t-\mathrm{Bu})_{3} \mathrm{Tl}$, but contrary to the alkali metal derivatives, they are monomeric. As a representative example, the skeleton of the cage of $\mathrm{Sn}(\mathrm{O}-t-\mathrm{Bu})_{3} \mathrm{In}$ is depicted in Figure 13. Recently, the cation $\mathrm{Sn}(\mathrm{O}-\mathrm{t}$ $\mathrm{Bu})_{3} \mathrm{~Pb}^{+}$, which is a component of the complex compound $\mathrm{Pb}_{7} \mathrm{Sn}_{6} \mathrm{I}_{8}(\mathrm{O}-t-\mathrm{Bu})_{18}$, ${ }^{103}$ has been found to have a structure very close to that of $\mathrm{Sn}(\mathrm{O}-t-\mathrm{Bu})_{3} \mathrm{Tl}{ }^{102}$

Another sort of cage is found in the tert-butoxygermanates, -stannates, and -plumbates of the divalent elements listed in Table VII; the core of Sn(O-t$\mathrm{Bu})_{3} \mathrm{Sr}(\mathrm{O}-t-\mathrm{Bu})_{3} \mathrm{Sn}$ is represented in Figure 13. Two $\mathrm{MO}_{3} \mathrm{M}^{\prime}$ trigonal bipyramids are fused together at the common $\mathrm{M}^{\prime}$ corner. Whereas the magnesium germanate $\mathrm{Ge}(\mathrm{O}-t-\mathrm{Bu})_{3} \mathrm{Mg}(\mathrm{O}-t-\mathrm{Bu})_{3} \mathrm{Ge}$ can be obtained easily following reactions (16), the corresponding stannate does not exist; instead a magnesium tin compound is isolated which has a dispiro structure: ${ }^{105}$ 


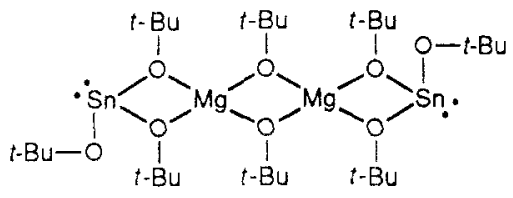

In place of $\mathrm{Mg}^{2+}$, the transition element cations such as $\mathrm{Ni}^{2+}, \mathrm{Co}^{2+}, \mathrm{Mn}^{2+}, \mathrm{Cr}^{2+}$, etc. can be incorporated in this stannate and still maintain the structure. ${ }^{99}$

It is evident from these findings that the radius of the metal and the nature of the low-valent group IV element seem to influence the structure type adopted by the metal germanates, stannates, and plumbates.

Two other compounds of Table VII need some further comment. Whereas the compound $\mathrm{Ge}(\mathrm{O}-t$ $\mathrm{Bu})_{3} \mathrm{~Pb}(\mathrm{O}-\mathrm{t}-\mathrm{Bu})_{3} \mathrm{Ge}$ has a threefold axis, $\mathrm{Sn}(\mathrm{O}-\mathrm{t}$ $\mathrm{Bu})_{3} \mathrm{~Pb}(\mathrm{O}-t-\mathrm{Bu})_{3} \mathrm{Sn}$ lacks this symmetry element. In the first compound the three metal atoms are in a linear arrangement, but they are nonlinear in the second case, the $\mathrm{Sn} \cdots \mathrm{Pb} \cdots \mathrm{Sn}$ angle amounting to $172^{\circ}$. The nonbonding electron pair on the lead atom is stereochemically active in the tin compound and seems to be negligible ("inert") in the germanium analogue. As can be seen by low-temperature diffraction techniques, in the case of the germanium derivative a phase transition is observed around $-130^{\circ} \mathrm{C}$. This seems to occur with loss of the threefold axis. ${ }^{103}$

The bonding of the central metals $\mathrm{M}^{\prime}$ in $\mathrm{M}(\mathrm{O}-t$ $\mathrm{Bu})_{3} \mathrm{M}^{\prime}(\mathrm{O}-t-\mathrm{Bu})_{3} \mathrm{M}$ can be described in two ways. In the first model, a $\mathrm{M}^{2+}$ cation is located in the middle of a distorted $\mathrm{O}_{6}$ octahedron, the $(t-\mathrm{BuO})_{3} \mathrm{M}$ part of the molecule bearing the negative charge (the $\mathrm{Sr}-\mathrm{O}$ distances in $\mathrm{Sn}(\mathrm{O}-t-\mathrm{Bu})_{3} \mathrm{Sr}(\mathrm{O}-t-\mathrm{Bu})_{3} \mathrm{Sn}(2.523$ (3) $\AA$ ) are comparable with the $\mathrm{Sr}-\mathrm{O}$ distances in solid $\mathrm{SrO}^{107}$ $(2.580 \AA))$. The tert-butyl groups "envelope" the $\mathrm{O}_{6} \mathrm{M}^{\prime}$ part of the molecule in such a perfect way that its high solubility in benzene can be explained. In the second model, the metal is coordinated by the oxygen atoms very similarly to Lewis acid-base interactions of lighter metallic elements. ${ }^{19}$ In the compounds with the simple $\mathrm{MO}_{3} \mathrm{M}^{\prime}$ cage, the interactions of the oxygen and metal atoms are presumably of this coordination type, as again these molecules are almost nonpolar, very soluble in benzene or hexane, and easily sublimable. Generally, $\mathrm{Ge}(\mathrm{II}), \mathrm{Sn}(\mathrm{II})$, and $\mathrm{Pb}$ (II) have higher $\mathrm{O}-\mathrm{M}-\mathrm{O}$ angles $\left(75-83^{\circ}\right)$ than the monovalent In or $\mathrm{Tl}$ atoms $\left(63-70^{\circ}\right){ }^{101}$

\section{Some Remarks on Metal/Nonmetal Cages and Uses}

The cages formed by metals and nonmetals presented so far are only a small section of compounds, which can be extended arbitrarily.

As mentioned in the introduction, additional ligands on the metal sites that act as donors may influence the properties of the metal considerably.

While lithium chloride forms an ionic lattice, it can be dissolved in hexamethylphosphorus acid triamide (hmpt) and crystallized as $\left[\left(\mathrm{Me}_{2} \mathrm{~N}\right)_{3} \mathrm{PO} \cdot \mathrm{LiCl}\right]_{4} \cdot{ }^{108}$ In the crystal one sees an $\mathrm{Li}_{4} \mathrm{Cl}_{4}$ cube with hmpt coordinating at four corners on the lithium atoms through metaloxygen linkages. As may be deduced from this example, the steric requirement of the ligand and the reduced electrophilicity of the metal do strongly change the bonding from lithium to chlorine. Another interesting example is again taken from the work of Snaith and co-workers. The imino lithium compound $\left[\mathrm{Ph}_{2} \mathrm{C}=\right.$ $\mathrm{NLi} \cdot \mathrm{py}]_{4}$, which can be obtained from pyridine solutions of the imide, is tetrameric $\left(\mathrm{Li}_{4} \mathrm{~N}_{4}\right.$ cubic cage). ${ }^{108}$ If the same imide is dissolved in hmpt, no tetramer is obtained; instead the salt $\left[\mathrm{Li}(\mathrm{hmpt})_{4}\right]\left[\mathrm{Li}(\mathrm{hmpt}) \mathrm{Li}_{4}(\mathrm{~N}=\right.$ $\left.\left.\mathrm{CPh}_{2}\right)_{6}\right]$, which contains in the anionic part a $\mathrm{Li}_{5} \mathrm{~N}_{6}$ cage, is obtained. ${ }^{109}$ The structure of this cage is, in a simplified view, analogous to the $\mathrm{N}_{4} \mathrm{Ge}_{3} \mathrm{H}_{3} \mathrm{Cl}$ cage of $(t$ $\mathrm{BuN})_{4} \mathrm{Ge}_{3} \mathrm{H}_{3} \mathrm{Cl}$ (see section III.B), but inversed ("anti") with respect to the sites of the metallic and nonmetallic atoms. If the phenyl groups are replaced by dimethylamino or tert-butyl substituents in the lithium imides, hexamers crystallize, which have no further solvent ligand at the lithium atoms. The $\mathrm{Li}_{6} \mathrm{~N}_{6}$ cages in $\left[\mathrm{LiN}=\mathrm{C}\left(\mathrm{NMe}_{2}\right)_{2}\right]_{6}$ and $\left[\mathrm{LiN}=\mathrm{C}(t-\mathrm{Bu})_{2}\right]_{6}$ are comparable to the $\mathrm{Li}_{6} \mathrm{C}_{6}$ arrangement that is found in hexameric lithium alkyls (see section III.B). ${ }^{110}$

It is interesting to note that despite the different formal hybridization of nitrogen in an imino compound $\left(\mathrm{sp}^{2}\right)$ such as $\left[\mathrm{Ph}_{2} \mathrm{C}=\mathrm{NLi} \cdot \mathrm{py}\right]_{4}{ }^{108}$ compared to oxygen $\left(\mathrm{sp}^{3}\right)$ in an enolate such as $\left[\mathrm{Li}\left(\mathrm{OC}_{5} \mathrm{H}_{7}\right) \cdot \mathrm{THF}\right]_{4}$, ${ }^{87}$ the structures are at a first sight comparable. Only a closer look will reveal that in the enolate compound the lithium atoms are $2.66 \AA$ apart, whereas in the enolate their intramolecular distance is $2.31 \AA$. This seems to reflect the poorer electron concentration on nitrogen compared to oxygen.

Three very different examples can be cited to demonstrate the chemical uses of such metal/nonmetal cages. Seebach has stated in a review dedicated to lithium enolates that their ability to form $\mathrm{C}-\mathrm{C}$ bonds could easily be interpreted in terms of their nucleophilicity; nevertheless, an understanding of the reaction mechanisms and of the stereoselectivity could only be done on the basis of the three-dimensional structures. ${ }^{30}$

The hexamer ( $\mathrm{HAlN}-i-\mathrm{Pr})_{6}$ has been used in reduction processes: it reduces aldehydes and ketones to alcohols in good yields; ${ }^{111}$ it is also suitable to reduce selectively dicarbonyl compounds. ${ }^{112}$ In conjunction with cobalt and nickel compounds, it can also serve for the hydrogenation of olefins. ${ }^{113}$

Recently, we have been able to demonstrate that the mixed metal alkoxides of the series $\mathrm{M}(\mathrm{O}-\mathrm{t}-\mathrm{Bu})_{3} \mathrm{M}^{\prime}(\mathrm{O}$ $t$-Bu) ${ }_{3} \mathrm{M}$ or $\mathrm{M}(\mathrm{O}-t-\mathrm{Bu})_{3} \mathrm{M}^{\prime}$ (see section III.C) can be used as starting materials for polymetal/nonmetal bridged chains. ${ }^{99}$ To take $\mathrm{Sn}(\mathrm{O}-t-\mathrm{Bu})_{3}$ In as an example, it can be used to react with metal carbonyls to form metal-metal bonds. As the tin and the indium atoms in the cage compound have nonbonding electron pairs and these two atoms are structurally speaking on opposite "faces" of the molecule, we have designated them as "Janus-type molecules". In eqs 17-19 some representative examples for the reactivity of $\operatorname{In}(\mathrm{O}-t-\mathrm{Bu})_{3} \mathrm{Sn}$ are depicted.

$$
\begin{aligned}
& \operatorname{In}(\mathrm{O}-t-\mathrm{Bu})_{3} \mathrm{Sn} \stackrel{+\mathrm{Mo}(\mathrm{CO})_{6}}{-\mathrm{CO}} \mathrm{Sn}(\mathrm{O}-t-\mathrm{Bu})_{3} \mathrm{In}-\mathrm{Mo}(\mathrm{CO})_{5} \\
& \stackrel{+(\mathrm{CO})_{5} \mathrm{Cr}(\mathrm{thf})}{\longrightarrow}(\mathrm{CO})_{5} \mathrm{Cr}-\mathrm{Sn}(\mathrm{O}-t-\mathrm{Bu})_{3} \mathrm{In}-\mathrm{Mo}(\mathrm{CO})_{5}(17 \mathrm{a}) \\
& - \text { thf } \\
& \operatorname{In}(\mathrm{O}-\mathrm{t}-\mathrm{Bu})_{3} \mathrm{Sn} \stackrel{+\mathrm{Cr}(\mathrm{CO})_{6}}{\longrightarrow} \mathrm{Cn}(\mathrm{O}-t-\mathrm{Bu})_{3} \mathrm{In}-\mathrm{Cr}(\mathrm{CO})_{5} \\
& \stackrel{+(\mathrm{CO})_{5} \mathrm{Mo} \cdot \mathrm{THF}}{\longrightarrow}(\mathrm{CO})_{5} \mathrm{Mo}-\mathrm{Sn}(\mathrm{O}-t-\mathrm{Bu})_{3} \mathrm{In}-\mathrm{Cr}(\mathrm{CO})_{5} \\
& - \text { thf }
\end{aligned}
$$




$$
\begin{aligned}
& 2 \operatorname{In}(\mathrm{O}-t-\mathrm{Bu})_{3} \mathrm{Sn}+(\mathrm{nbd}) \mathrm{Mo}(\mathrm{CO})_{4} \underset{-\mathrm{nbd}}{\longrightarrow} \\
& \quad \mathrm{Sn}(\mathrm{O}-t-\mathrm{Bu})_{3} \mathrm{In}-\mathrm{Mo}(\mathrm{CO})_{4}-\mathrm{In}(\mathrm{O}-t-\mathrm{Bu})_{3} \mathrm{Sn}
\end{aligned}
$$

$$
\mathrm{Sn}(\mathrm{O}-t-\mathrm{Bu})_{3} \mathrm{In}-\mathrm{Mo}(\mathrm{CO})_{4}-\mathrm{In}(\mathrm{O}-t-\mathrm{Bu})_{3} \mathrm{Sn} \frac{+2 \mathrm{Cr}(\mathrm{CO})_{6}(\text { thf })}{- \text { thf }}
$$$$
(\mathrm{CO})_{5} \mathrm{Cr}-\mathrm{Sn}(\mathrm{O}-t-\mathrm{Bu})_{3} \mathrm{In}-\mathrm{Mo}\left(\mathrm{CO}_{4}\right)-\mathrm{In}(\mathrm{O}-t-\mathrm{Bu})_{3} \mathrm{Sn}-\mathrm{Cr}
$$

As may be seen in eqs $17 \mathrm{a}, \mathrm{b}$ the isomers $(\mathrm{CO})_{5} \mathrm{Cr}-$ $\mathrm{Sn}(\mathrm{O}-t-\mathrm{Bu})_{3} \mathrm{In}-\mathrm{Mo}(\mathrm{CO})_{5}$ and $(\mathrm{CO})_{5} \mathrm{Mo}-\mathrm{Sn}(\mathrm{O}-t-\mathrm{Bu})_{3} \mathrm{In}-$ $\mathrm{Cr}(\mathrm{CO})_{5}$ can be synthesized separately by using the higher tendency of indium(I) to coordinate to the transition-metal fragment. Whereas in these two isomers four metal atoms are aligned, there are five in the product of eq 18 or seven in the product of eq 19. These last two products are bent at the central molybdenum atom, the cis arrangement being preferred over the trans.

\section{Conclusion}

The variety of cages in main-group metal alkyls, amides, and alcoholates is astonishing, but nevertheless explicable on the basis of simple models. The metal, the nonmetal, and the substituents at the nonmetal are responsible for the structure adopted by the compound. "Solvent ligands" on the metal atoms seem to influence the structure as well. A last quite complex example may be taken from enolates. Whereas the sodium compound $\left[\mathrm{NaOC}(t-\mathrm{Bu}) \mathrm{CH}_{2} \cdot \mathrm{OCMe}(t-\mathrm{Bu})\right]_{4}$ forms an $\mathrm{Na}_{4} \mathrm{O}_{4}$ cube, the potassium compound $\left[\mathrm{KOC}(t-\mathrm{Bu}) \mathrm{CH}_{2} \cdot \mathrm{THF}\right]_{6}$ is hexameric with a hexagonal prismatic $\mathrm{K}_{6} \mathrm{O}_{6}$ core. ${ }^{114}$ Going from the sodium to the potassium compound, not only does the metal change but also does the solvent donor at the metal, and these two facts may be responsible for the different structures. On the other hand, we have found many examples where, despite the same composition, several different oligomers can be formed.

\section{Acknowledgments}

I thank my co-workers (see references) for their valuable contributions to this so rapidly expanding field of metal/nonmetal cages. We are grateful for financial support from the Fonds der Chemischen Industrie and the Deutsche Forschungsgemeinschaft.

\section{References}

(1) Kepler, J. De Figuram Regularium, Austria, Anno 1619.

(2) Maier, G.; Pfriem, S.; Schäfer, U.; Malsch, K.-D.; Matusch, R. Chem. Ber. 1981, 114, 3965.

(3) (a) Eaton, P. E.; Cole, T. W. J. Am. Chem. Soc. 1964, 86, 3157. (b) Barborak, J. C.; Watts, L.; Pettit, R. J. Am. Chem. Soc. $1966,88,1328$.

(4) Griffin, G. W,; Marchand, A. P. Chem. Rev, 1989, 89, 997.

(5) (a) Paquette, L. A.; Ternansky, R. J.; Balogh, D. W.; Kentgen, G. J. Am. Chem. Soc. 1983, 105, 5446. (b) Paquette, L. A. Chem. Rev. 1989, 89, 1051 .

(6) Katz, T. J.; Acton, N. J. Am. Chem. Soc. 1973, 95, 2738.

(7) Eaton, P. E.; Or, Y. S.; Branca, S. J. J. Am. Chem. Soc. 1981, 103,2134

(8) Musso, H.; Biethan, U. Chem. Ber. 1967, 106, 119.

(9) (a) Rheingold, A. L. Homoatomic Rings, Chains and Macromolecules of Main Group Elements; Elsevier: Amsterdam, 1977. (b) Haiduc, I.; Sowerby, D. B. The Chemistry of Inorganic Homo- and Heterocycles; Academic Press: London, 1987.

(10) The Royal Society, London Metal Clusters in Chemistry; Cambridge University Press: Cambridge, 1983.
(11) Xavier, A. V.; Moura, J. J. G.; Moura, I. Struct. Bonding $1983,53,59$.

(12) Corbridge, D. E. C. The Structural Chemistry of Phosphorus; Elsevier: Amsterdam, 1973.

(13) Fritz, G.; Matern, E. Carbosilanes-Syntheses and Structures; Springer: Berlin, 1986.

(14) Pearson, A. G. Hard and Soft Bases and Acids; Dowdon/ Hutchinson/Ross, Stroudsburg, PA, 1973.

(15) (a) Wood, G. L.; Duesler, E. N.; Paine, R. T.; Nöth, H. Phosphorus, Sulfur Silica 1989, 41, 267. (b) Gimarc, B. M.; Ott, J. J. J. Am. Chem. Soc. 1986, 108, 4293. (c) Kakimoto, N. Heterocycles 1985, 23, 2681. (d) Blecher, A.; Mathiasch, B.; Dräger, H. Z. Anorg. Allg. Chem. 1982, 488, 177 . (e) Dräger, M.; Mathiasch, B. Angew. Chem., Int. Ed. Engl. 1981, 20, 1048. (f) Neubert, W.; Pritzkow, H.; Latscha, H. P. Angew. Chem., Int. Ed. Engl. 1988, 27, 287. (g) Wettling, T.; Schneider, J.; Wagner, O.; Kreiter, C. G.; Regitz, M. Angew. Chem. 1989, 101, 1035; Angew. Chem., Int. Ed. Engl. 1989, 28, 1013. (h) Baudler, M.; Scholz, G.; Tebbe, K.-F.; Fêher, M. Angew. Chem., Int. Ed. Engl. 1989, 28, 339. (i) Henkel, G.; Krebs, B.; Betz, P.; Fietz, H.; Saatkamp, K. Angew. Chem., Int. Ed. Engl. 1989, 27, 1326. (j) Fenske, P.; Ohmer, J.; Hachgenei, J.; Merzweiler, K. Angew. Chem., Int. Ed. Engl. 1988, 27, 1277. (k) Schubert, D. M.; Manning, M. J.; Hawthorne, M. F. Phosphorus, Sulfur Silica 1989, 41, 253

(16) (a) Weiss, E.; Alsdorf, H. Z. Anorg. Allg. Chem. 1970, 372, 206. (b) Weiss, E.; Alsdorf, H.; Kühr, H. Angew. Chem., Int Ed. Engl. 1967, 6, 801.

(17) (a) Bradley, D. C. Adu. Inorg. Chem. Radiochem. 1972, 15, 259. (b) Mehrotra, R. C. Adv. Inorg. Chem. Radiochem. 1983, 26, 269. (c) Bradley, D. C.; Mehrotra, R. C.; Gaur, D. P. Metal Alkoxides; Academic Press: London, 1978.

(18) (a) Milne, T. A.; Cubicciotti, D. J. Chem. Phys. 1958, 29, 846. (b) Akishin, P. A.; Rambidi, N. G. Z. Phys. Chem. (Leipzig) $1960,213,111$.

(19) (a) Gutmann, V. The Donor-Acceptor Approach to Molecular Interactions; Plenum: New York, 1978. (b) Haaland, A. Angew. Chem. 1989, 101, 1017; Angew. Chem., Int. Ed. Engl. 1989, 28, 992 .

(20) Del Piero, G.; Cesari, M.; Dozzi, G.; Mazzei, A. J. Organomet. Chem. 1977, 129, 281.

(21) Veith, M.; Recktenwald, O. Z. Naturforsch. 1983, B38, 1054.

(22) Veith, M.; Recktenwald, O. Top. Curr. Chem. 1982, 104, 1.

(23) Veith, M. Angew. Chem., Int. Ed. Engl. 1987, 26, 1.

(24) Cesari, M.; Perego, G.; Del Piero, G.; Cucinella, S.; Cernia, E. $J$. Organomet. Chem. 1974, 78, 203.

(25) Dahl, L. F.; Davies, G. L.; Wampler, D. L.; West, K. J. Inorg. Nucl. Chem. 1962, 24, 357.

(26) Recktenwald, O. Thesis, University of Braunschweig, 1984.

(27) (a) Weiss, E.; Lucken, E. A. C. J. Organomet. Chem. 1964, 2, 197. (b) Weiss, E.; Hencken, G. J. Organomet. Chem. 1978, 21, 265. (c) Kaufmann, E.; Raghavachari, K.; Reed, A. E.; von Ragué Schleyer, P. Organometallics 1988, 7, 1597.

(28) (a) von Ragué Schleyer, P. Pure Appl. Chem. 1984, 56, 151. (b) Setzer, W. N.; von Rague Schleyer, P. Adv. Organomet. Chem. 1985, 24, 353 .

(29) Schlosser, M. Struktur und Reaktivität polarer Organometalle; Springer: Berlin, 1973.

(30) Seebach, D. Proceedings of the Robert A. Welch Foundation. Conferences on Chemical Research XXVII. Stereospecificity in Chemistry and Biochemistry, Houston, TX, 1984.

(31) Schade, C.; von Ragué Schleyer, P. Adv. Organomet. Chem. $1987,27,169$.

(32) Weiss, E.; Sauermann, G.; Thirase, G. Chem. Ber. 1983, 116 , 74 .

(33) Brown, T. L.; Gerteis, R. L.; Bafus, D. A.; Ladd, J. A. J. Am. Chem. Soc. 1964, 86, 2135.

(34) (a) McKeever, L. D.; Waack, R. J. Chem. Soc. D 1969, 750 (b) Scovell, W. M.; Kimura, B. Y.; Spiro, T. G. J. Coord Chem. 1971, 1, 107 .

(35) Zerger, R.; Rhine, W.; Stucky, G. J. Am. Chem. Soc. 1974, 96, 6048.

(36) Kösler, H.; Thönnes, D.; Weiss, E. J. Organomet. Chem. 1978, 160,1 .

(37) Geissler, M.; Kopf, J.; Schubert, B.; Weiss, E. Angew. Chem., Int. Ed. Engl. 1987, 26, 569.

(38) Weiss, E.; Kopf, J.; Schubert, B.; Neugebauer, W. Kos, A. In von Ragué Schleyer, P. Pure Appl. Chem. 1984, 56, 151.

(39) Hope, H.; Power, P. P. J. Am. Chem. Soc. 1983, 105, 5320.

(40) Schmidbaur, H.; Schier, A.; Schubert, U. Chem. Ber. 1983. $116,1938$.

(41) Klumpp, G. W.; Guerink, P. J. A.; Spek, A. L.; Duisenberg, J. M. J. Chem. Soc., Chem. Commun. 1983, 814

(42) Jastrzebski, J. T. B. H.; van Koten, G.; Koniju, M.; Stam, C. H. J. Am. Chem. Soc. 1982, 104, 5490 . 
(43) Harder, S.; Boersma, J.; Brandsma, L.; van Heteren, A.; Kanters, J. A.; Bauer, W.; von Ragué Schleyer, P. J. Am. Chem. Soc, 1988, 110, 7802.

(44) Lappert, M. F.; Power, P. P.; Sanger, A. R.; Srivastava, R. C.; Metal and Metalloid Amides; Wiley: New York, 1980.

(45) Brauer, D. J.; Bürger, H.; Liewald, G. R. J. Organomet. Chem. 1986, 308, 119 .

(46) Brauer, D. J.; Bürger, H.; Geschwandtner, W.; Liewald, S. R. Krüger, C. J. Organomet. Chem. 1983, 248, 1

(47) Brauer, D. J.; Bürger, H.; Liewald, G. R.; Wilke, J. J. Organomet. Chem. 1985, 287, 305.

(48) Pöhlmann, J. Thesis, Universität des Saarlandes, Saarbrücken, 1986. Veith, M.; Pöhlmann, J.; Spaniol, A., unpublished results.

(49) Del Piero, G.; Cesari, M.; Mazzei, A. J. Organomet. Chem. $1977,137,265$.

(50) Veith, M.; Goffing, F.; Huch, V. Chem. Ber. 1988, 121, 943

(51) Veith, M.; Sieren, H., unpublished results.

(52) Veith, M.; Goffing, F.; Huch, V.Z. Naturforsch. 1988, B43, 846.

(53) Veith, M.; Frank, W.; Töllner, F.; Lange, H. J. Organomet. Chem. 1987, 326, 315

(54) Veith, M.; Harine, M., unpublished results.

(55) Veith, M.; Lengert, A., unpublished results.

(56) Cesari, M.; Cucinella, S. In Haiduc, I.; Sowerby, D. B., Eds.; The Chemistry of Inorganic, Homo- and Heterocycles; Aca. demic Press: London, 1987; Vol. I, p 167.

(57) Del Piero, G.; Cesari, M.; Dozzi, G.; Mazzei, A. J. Organomet. Chem. 1977, 129, 281.

(58) McDonald, T. R. R.; McDonald, W. S. Acta Crystallogr. 1972 , $B 28,1619$

(59) Del Piero, G.; Perego, G.; Cucinella, S.; Cesari, M.; Mazzei, A. J. Organomet. Chem 1977, 136,13.

(60) Hitchcock, P. B.; Smith. J. D.; Thomas, K. M. J. Chem. Soc., Dalton Trans. 1976, 1433 .

(61) Del Piero, G.; Cesari, M.; Perego, G.; Cucinella, S.; Cernia, E. J. Organomet. Chem. 1977, 129, 289 .

(62) Amirkhalili, S.; Hitchcock, P. B.: Smith, J. D. J. Chem. Soc., Dalton Trans. 1979, 1206

(63) Cucinella, S.; Salvatori, T.; Busetto, C.; Perego, G.; Mazzei, A. J. Organomet. Chem $1974,78,185$.

(64) Nöth, H.; Wolfgardt, P. Z. Naturforsch. 1976, B31, 697

(65) Thewalt, U.; Kewada, I. Chem. Ber. 1970, 103, 2754

(66) Perego, G.; Del Piero, G.; Cesari, M.; Zazzetta, A.; Dozzi, G. J. Organomet. Chem. 1975, 87, 53 .

(67) Veith, M. Comments Inorg. Chem. 1985, 4, 179

(68) Veith, M; Frank, W. Chem. Rev. 1988, 88, 81 .

(69) Veith, M.; Grosser, M. Z. Naturforsch. 1982, B37, 1375

(70) Veith, M.: Sommer, M.-L.: Jäger, D. Chem. Ber. 1979, 112 2581.

(71) Veith, M.; Schlemmer, G. Chem. Ber. 1982, 115, 2141

(72) Veith, M.; Becker, R., unpublished results.

(73) Veith, M.; Lange. H. Angeu. Chem., Int. Ed. Engl. 1980, 19, 401.

(74) Fischer, J. Thesis, Universität des Saarlandes, Saarbrücken, 1988.

(75) Spaniol, A. Thesis, Universität des Saarlandes, Saarbrücken, 1988

(76) Veith, M Chem Ber 1978, 111, 2536

(77) Veith, M.; Huch, V.; Lisowsky, R.; Hobein, P. Z. Anorg. Allg. Chem. 1989, 569, 43

(78) Veith, M.; Grosser, N.; Recktenwald, O. J. Organomet. Chem. $1981,216,27$.

(79) Veith, M; Frank, W. Angew. Chem., Int. Ed. Engl. 1984, 23, 158.

(80) Lindgren, J.: Olovsson, I. Acta Crystallogr. 1968, B24, 554.
(81) (a) Masamune, S.; Cuts, H.; Hogben, M. G. Tetrahedron Lett. 1966, 1017. (b) Marchand, A. P. Chem. Rev. 1989, 89, 1011

(82) Holmes, R. R. Acc. Chem. Res. 1989, 22, 190

(83) (a) Puff, H.; Reuter, H. J. Organomet. Chem. 1989, 368, 173. (b) Puff, H.; Reuter, H. J. Organomet. Chem. 1989, 373, 173.

(84) (a) Wheatley, P. J. J. Chem. Soc. 1960, 4270. (b) Weiss, E. Z. Anorg. Allg. Chem. 1964, 332, 197, (c) Weiss, E. Helv. Chim. Acta 1963, 46, 2061.

(85) Greiser, Th.; Weiss, E. Chem. Ber. 1979, 112, 844

(86) (a) Baius, M. S. Can. J. Chem. 1964, 42, 945. (b) Hartwell, G. E.; Brown, T. L. Inorg. Chem. 1966, 5, 1257

(87) Amstutz, R.; Schweizer, W. B.; Seebach, D.; Dunitz, J. D. Helv. Chim. Acta 1981, 64, 2617.

(88) Seebach, D.; Amstutz, R.; Laube, T.; Schweizer, W. B.; Dunitz, J. D. J. Am. Chem. Soc. 1985, 107, 5403 .

(89) Greiser, Th.; Weiss, E. Chem. Ber. 1977, 110, 3388

(90) (a) Weiss, E.; Alsdorf, H.; Kühr, H. Angew. Chem., Int. Ed. Engl. 1967, 6, 801. (b) Weiss, E.; Alsdorf, H.; Kühr, H.; Grützmacher, H. F. Chem. Ber. 1968, 101, 3777.

(91) Weiss, E.; Hoffmann, K.; Grützmacher, H. F. Chem. Ber. $1970,103,1190$

(92) (a) Turova, N. Y.; Popovkin, B. A.; Novoselova, A. V. Izv. Akad. Nauk SSSR, Neorg. Mat. 1967, 3, 1435. (b) Stäglich, H.; Weiss, E. Chem. Ber. 1978, 111, 901

(93) Mootz, D.; Zinnius, A.; Böttcher, B. Angew. Chem., Int. Ed. Engl. 1969, 8, 378

(94) Ashby, E. C.; Nackashi, J.; Parris, G. E. J. Am. Chem. Soc. $1975,97,3162$.

(95) Veith, M.; Koch, J., unpublished results.

(96) Harrison, P. G.; Haylett, B. J.; King, T. J. J. Chem. Soc., Chem. Commun. 1978, 112.

(97) Chandraseklar, V.; Day, O. R.; Holmes, R. R. Inorg. Chem. $1985,24,1970$.

(98) Kumara Swamy, K. C.; Day, O. R.; Holmes, R. R. J. Am. Chem. Soc. 1987, $109,5546$.

(99) Veith, M. Phosphorus, Sulfur Silica 1989, 41, 195

(100) Veith, M.; Rösler, R. Z. Naturforsch. 1986, B41, 1071.

(101) Kunze, T. Thesis, Universität des Saarlandes, Saarbrücken, 1988.

(102) Veith, M.; Rösler, R. Angew. Chem., Int. Ed. Engl. 1982, 21, 858.

(103) Hans, J. Thesis, Universität des Saarlandes, Saarbrücken,

(104) Veith, M.; Käfer, D.; Huch, V. Angew. Chem., Int. Ed. Engl. $1986,25,375$.

(105) Veith, M.; Käfer, D.; Stahl, L.; Huch, V., to be published.

(106) Koch, J. Thesis, Universität des Saarlandes, Saarbrücken, 1989.

(107) West, A. R. Solid State Chemistry; Wiley: Chichester, 1984; p 235 .

(108) Barr, D.; Clegg, W.; Mulvey, R. E.; Snaith, R. J. Chem. Soc., Chem. Commun. 1984, 79 .

(109) Barr, D.; Clegg, W.; Mulvey, R. E.; Snaith, R. J. Chem. Soc., Chem Commun 1984, 226.

(110) (a) Clegg, W.; Snaith, R.; Shearer, H. M. M.; Wade, K.; Whitehead, G. J. Chem. Soc., Dalton Trans. 1983, 1309. (b) Very recent results: Barr, D.; Clegg, W.; Hodgson, S. M.; Lamming, G. R.; Mulvey, R. E.; Scott, A. J.; Snaith, R.; Wright, D. S. Angew. Chem., Int. Ed. Engl. 1989, 28, 1241.

(111) Kriz, O.; Stuchlik, T.; Casensky, B. Z. Chem. 1977, 17, 18.

(112) Paradisi, M. P.; Zecchini, G. P. Tetrahedron 1981, 37, 971.

(113) Dozzi, G.; Cucinella, S.; Mazzei, A. J. Organomet. Chem. $1979,164,1$

(114) Willard, P. G.; Carpenter, G. B. J. Am. Chem. Soc. 1986, 108, 462 